\title{
Need and Options for
}

Subnational Scale Land-Use and Land-Cover Scenarios for the United States
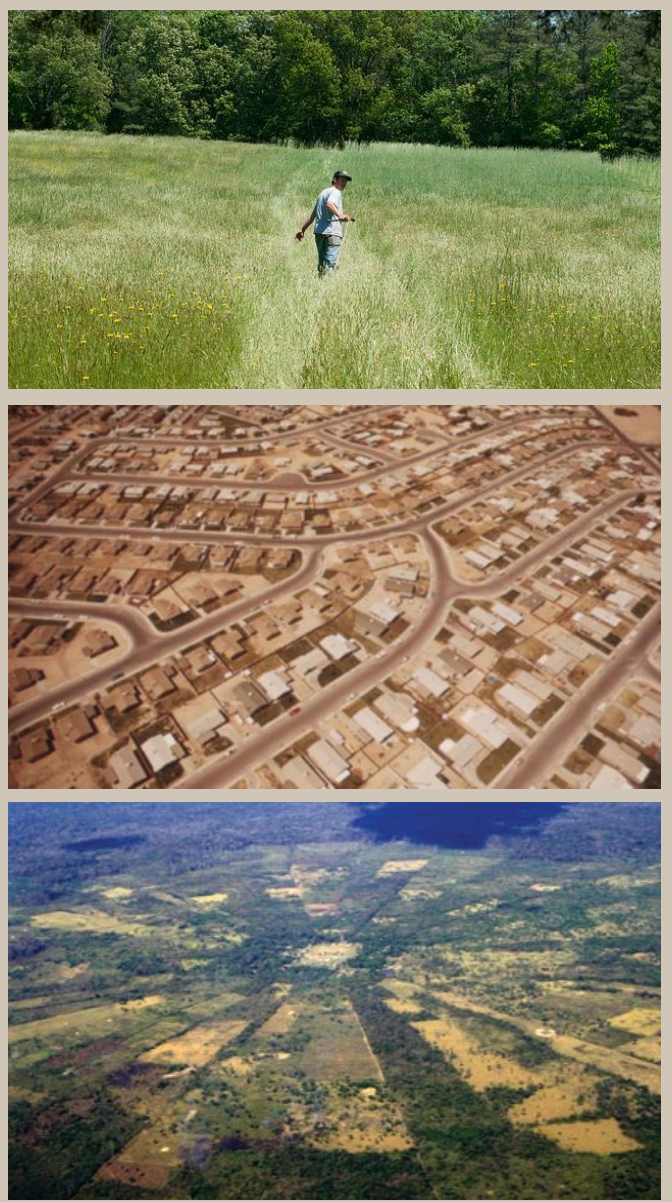

\section{January 2015}

Daniel Brown, ${ }^{*}$ Alison Delgado, ${ }^{\dagger}$ Richard Moss, ${ }^{\dagger}$ Fernando Sedano ${ }^{\ddagger}$

*University of Michigan, †Joint Global Change Research Institute/PNNL, $\neq$ University of Maryland

Report of a workshop organized under the auspices of the Scenarios and Interpretive Science Coordinating Group, and sponsored by the U.S. Department of Energy, National Aeronautics and Space Administration, U.S. Environmental Protection Agency and U.S. Department of Agriculture Forest Service 


\section{About the Scenarios and Interpretive Science Coordinating Group}

The Scenarios and Interpretative Science Coordinating Group (SISCG) of the United States Global Change Research Program fosters interagency collaboration with the goal of building the foundations for a coordinated U.S. scenario science enterprise. This effort is motivated by shared agency information needs for quantitative and qualitative scenario-related products aligned around regions, sectors, systems, and topics over spatial and temporal scales of interest. The major objectives of the SISCG include:

- Advancing collaborative science around critical knowledge gaps;

- Enhancing methodologies for use-inspired scenario development, risk framing, and contextual interpretation;

- Developing the next generation of scenario work products for model intercomparison efforts, national and international assessment, and related analyses; and

- Improving interagency communications, coordination, and accessibility to knowledge, work products, and technical resources. 


\section{Table of Contents}

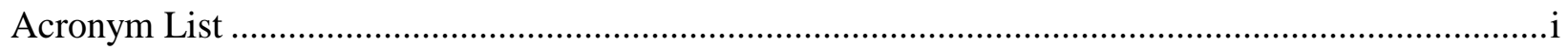

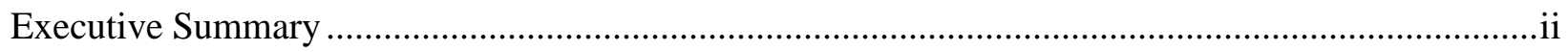

1. Introduction: Land-use and land-cover scenarios and their uses................................................

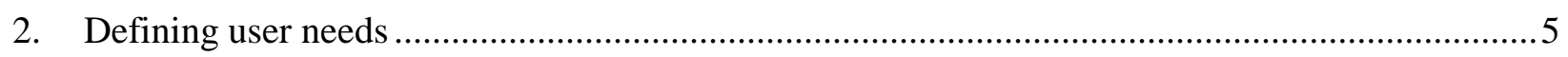

3. Land cover: existing and emerging data sets, models, and scenarios........................................... 9

4. Land use: existing and emerging data sets, models, and scenarios ............................................11

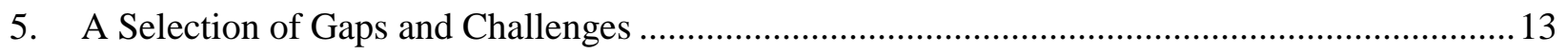

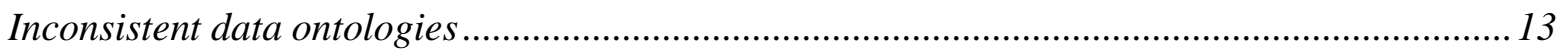

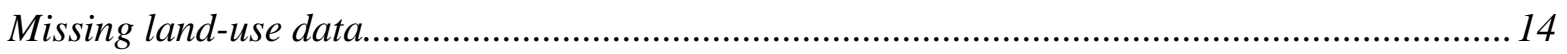

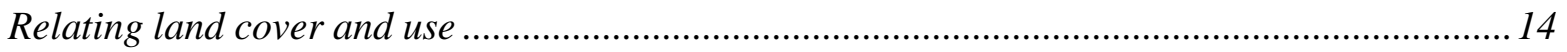

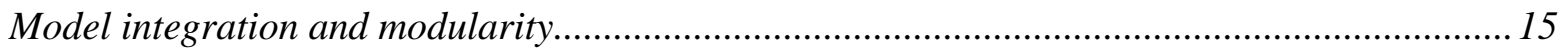

Uncertainty in projections under non-stationary and non-equilibrium conditions ......................15

Representing processes across scales ............................................................................... 16

6. Deepen understanding of suitability of current resources and user needs: regional and sectoral workshops and dialogue..................................................................................................... 16

7. Inventory and integration of existing and emerging resources: a national land cover/land use

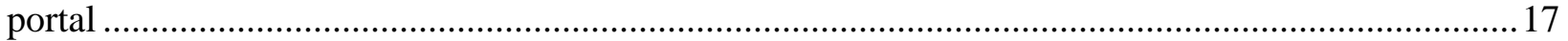

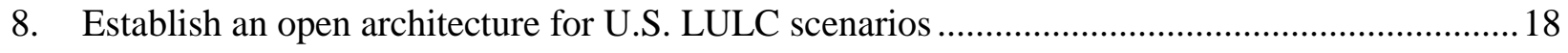

9. Develop capacity for integrated nested modeling ……...........................................................20

10. Options for next steps: program development and sustained effort ........................................2

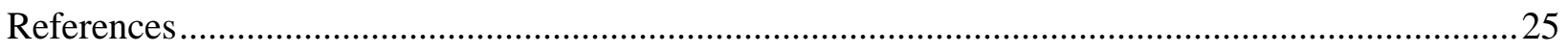

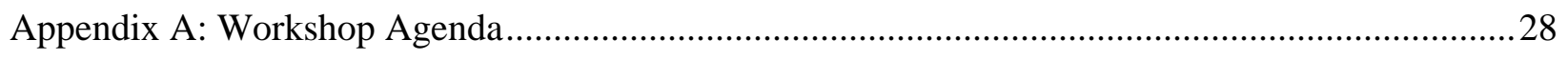

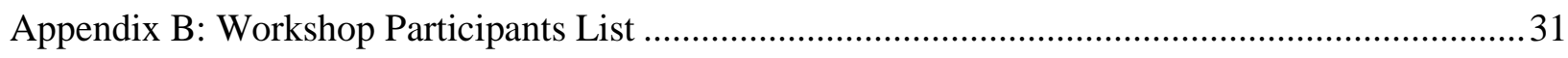

Appendix C: Workshop Science Steering Committee and Federal Coordinating Group Members ....33

Appendix D: List of Global Land Cover/Land Use Products .................................................................

Appendix E: List of National Land Cover/Land Use Products ............................................................36

Appendix F: List of National Land Cover/Land Use Trajectories......................................................39

\section{Figure and Tables}

Figure 1: Relationship of scenarios to other ways of thinking about the future ...................................2

Table 1: Core definitions .....................................................................................................

Table 2: Examples of federal agency needs for LULC scenarios ......................................................6

Table 3: Schematic summary of the land-use outcomes and drivers included in empirical and modeling work within different sectors. 


\section{Acronym List}

\begin{tabular}{|c|c|}
\hline CLM & Community Land Model \\
\hline CLUE & Conversion of Land Use and its Effects \\
\hline CMIP5 & Coupled Model Intercomparison Process Phase 5 \\
\hline DOD & Department of Defense \\
\hline DOE & Department of Energy \\
\hline DOI & Department of the Interior \\
\hline EPA & Environmental Protection Agency \\
\hline EPPA & Emissions Prediction and Policy Analysis \\
\hline EPSCoR & Experimental Program to Stimulate Competitive Research \\
\hline FORE-SCE & Forecasting Scenarios of Land-use Change model \\
\hline GCAM & Global Change Assessment Model \\
\hline GHG & Greenhouse gas \\
\hline GLM & Global Land Use Model \\
\hline GTAP & Global Trade Analysis Project \\
\hline ICLUS & Integrated Climate and Land Use Scenarios \\
\hline IPCC & Intergovernmental Panel on Climate Change \\
\hline LANDFIRE & Landscape Fire and Resource Management Planning Tools Project \\
\hline LTM & Land Transformation Model \\
\hline LULC & Land use and land cover \\
\hline NASA & National Aeronautics and Space Administration \\
\hline NCA & National Climate Assessment \\
\hline NLCD & National Land Cover Dataset \\
\hline NOAA & National Oceanic and Atmospheric Administration \\
\hline NRC & National Research Council \\
\hline NRI & National Resources Inventory \\
\hline PNNL & Pacific Northwest National Laboratory \\
\hline PRIMA & Platform for Regional Integrated Modeling and Analysis \\
\hline PUMS & Public-use micro-sample \\
\hline $\mathrm{RCP}$ & Representative Concentration Pathway \\
\hline RIAM & Regional Integrated Assessment Model \\
\hline RISA & Regional Integrated Sciences and Assessment \\
\hline RPA & Resources Planning Act \\
\hline SISCG & Scenarios and Interpretive Science Coordinating Group \\
\hline SRES & Special Report on Emissions Scenarios \\
\hline SSP & Shared Socioeconomic Pathway \\
\hline USDA & U.S. Department of Agriculture \\
\hline USGCRP & U.S. Global Change Research Program \\
\hline USGS & U.S. Geological Survey \\
\hline VGI & Volunteered geographic information \\
\hline
\end{tabular}




\section{Executive Summary}

\section{Background and purpose}

Scenarios of future climate, environmental, and socioeconomic conditions are used as inputs to global change research and assessment. Scenarios are plausible futures that do not convey the probability that the events described in the scenario will occur. They can be narrative by describing the overall trends and logic of future events in an internally consistent manner, quantified by rigorously calculating the consequences of the plausible trends using numerical models, or both. Research on global environmental processes, such as climate change, has advanced to the point where national-scale, regionally-differentiated, and spatially-explicit land use and land cover (LULC) scenarios for the United States are needed to improve both projections and assessments of the impacts of future climate conditions and bridge from global processes to regional and local conditions.

This report summarizes discussions during a workshop of users and producers of LULC scenarios convened by the Scenarios and Interpretive Science Coordinating Group of U.S. Global Change Research Program (USGCRP) on June 25-27, 2014. Participants at the workshop explored the state of science of LULC and opportunities for producing LULC scenarios for the United States at a subnational scale. The workshop identified critical uncertainties in projecting changes in land use/land cover, considered data and modeling capabilities, and explored elements of quantitative and qualitative scenarios of land use/land cover change that can be used by federal agencies to support multiple needs. This report focuses on needs, resources/capabilities, and barriers/opportunities for producing national-scale, regionallydifferentiated, and spatially-explicit LULC scenarios for the United States. It describes options for agency and interagency activities that would advance this research but makes no recommendations.

\section{Needs}

USGCRP is evaluating scenario needs for a number of interagency applications. For example, scenarios are needed for the sustained assessment process that was proposed by the National Climate Assessment Development and Advisory Committee and is part of the 2012 USGCRP Strategic Plan. USGCRP has also expressed a need for U.S.-based LULC scenarios to support individual agency research and management missions, such as for greenhouse gas reporting, fire and fuels planning and management, and impacts of population growth on land conversion. A few agencies have or are developing LULC scenarios (e.g., U.S. Department of Interior Geological Survey and U.S. Environmental Protection Agency), and other agencies, like National Aeronautics and Space Administration, do not directly support development of LULC scenarios, but have many programs that fund foundational research that informs scenarios development. LULC scenarios are needed by program managers, resource planners, and even private corporations and citizens confronting the need to consider changing environmental conditions for decision-making on investments and management options. 


\section{Existing and emerging resources}

The report provides a brief overview of existing and emerging LULC resources (i.e., data, models, and projections) that were discussed during presentations and discussions at the workshop. Resources for land cover are more widely available than for land use.

\section{Land cover}

The need and operational capabilities for collecting land-cover data are well established in the Earth observation community. Existing global LULC data sets are mostly gridded products obtained from remote sensing data. At the national level, several U.S. agencies and institutions have generated thematic products to serve their missions. These products comprise gridded datasets, surveys, and products combining both. Because remote sensing is a main source of land-cover products, classification systems are limited by the characteristics of the remote sensing system used to generate the products. These land-cover products are often not consistent and present limited interoperability. This is particularly evident in global datasets, with classification systems of varying complexity in which the lack of thematic coherence often prevents the comparison and integration of products. Active sensors such as LiDAR are already providing 3-D information about land surfaces and allow the capture of previously poorly quantified variables (biomass, building density) and a more precise representation of land surfaces. Products providing land-cover projections are scarce. Such products are commonly built using hybrid land-change models, commonly fit to historical data. National-scale products are often limited by the lack of consistent and reliable historic information, and are often focused on single sectors or land covers (e.g. impervious surfaces). Projecting future trajectories will require a better and more integrated understanding of processes linking policy frameworks, human behavior, and land-use change.

\section{Land use}

Traditionally, national-level land-use scenarios have been part of the output from global models that link land use to global climate and economic changes, and at more disaggregate scales using spatial econometric models. Many federal agencies collect land-use data, though often the coverage of these data is limited, and formatting is inconsistent. Agent-based land-use models have not yet been developed that would support production of national-scale scenarios, but at finer scales, in local settings, and for specific sectors, they have been used to study the implications of price, policy, and environmental changes on land-use responses and impacts. Research on drivers and processes of land-use change has been essential to developing models that can project future land-use patterns under alternative assumptions of socioeconomic and environmental conditions. This research has been carried out for different sectors, often separately, and at different scales. Modeling approaches that tend to be used to project land use are those that have a richer structural representation of decision making by land owners and managers. There are a number of global Integrated Assessment Models that estimate the amount of land in different land-use categories based on computable general and partial equilibrium models. These models account for demand and supply of commodities in many regions of the world, along with trade among those regions. Emergent approaches that better integrate these global models with spatially disaggregated patterns are currently under development. 


\section{Gaps and challenges}

The report summarizes existing research gaps and barriers to development of U.S. LULC scenarios that were highlighted at the workshop. Among some of the major gaps identified are inconsistent data ontologies; missing land-use data; relating land cover and use; model integration and modularity; uncertainty in projections under non-stationary and non-equilibrium conditions; and representation of processes across scales. There is a palpable need for an extended and nationally-coordinated land-use observational strategy. Some participants also argued that data harmonization was a larger problem than access. Different data sets are available for land cover and use that are not cross-referenced or compared in a meaningful way, thus providing a poor foundation for modeling. Model integration across scales would allow better representation of the interactions among land-change patterns and processes, but this also faces some challenges, namely consequences for the computational burden and challenges in assessing uncertainty. When environmental or social conditions are changing (i.e., are nonstationary) or where feedbacks play a strong role in determining future amounts and patterns of LULC, uncertainties can be amplified.

The way in which global- and national-scale dynamics in population, economics, climate, and other factors influence inter-regional dynamics in U.S. land demand, and the way these changes manifest differently across regions and localities, argues for a modeling approach that takes on a nested structure.

\section{Addressing gaps and opportunities}

Sections 6 through 9 of the report describe key potential options for addressing some of the gaps and opportunities identified at the workshop. An issue raised in several break-out group and plenary discussions is informing national LULC scenarios with more specific information on how users would like to make use of them and what issues they would like them to address. Many participants felt that it would be a useful exercise to continue to refine a list of LULC drivers, focusing on importance, level of uncertainty, and feasibility. Regional/local organizations will be helpful in identifying and integrating relevant information (through the Regional Integrated Sciences and Assessment programs, for example), particularly because it is frequently the regional scale information on land use that is missing.

Two major opportunities for the LULC science and modeling communities are to innovate on the types of data available and work to better integrate and share existing data resources. Advances in remote sensing data collection and distribution approaches present important opportunities for enhancing data availability. Alternative and innovative methods for collecting geocoded information, particularly relating to land use, are the use of volunteered geographic information, surveys implemented on mobile devices, and data extraction from commercial social networking and other sites. In addition, a common platform for data synthesis and integration would benefit development of integrated models. Incorporating human land-cover change and landmanagement processes into models is an on-going top research priority. 
Global-level scenarios and global Integrated Assessment Models can provide context and a common set of assumptions for more spatially explicit and regionally and sectorally specific assessments at lower levels. Modeling approaches at the national to regional scale might be most effective for understanding changes in the inter-regional distributions of land-use activities and spatially resolved at the county scale. Regional economic and demographic models can serve as a platform for identifying differential rates of change, redistributions of population and economic activity, and inclusion of regionally-specific environmental change projections.

Because of the varied scales at which variables drive land-use change, and the multiple scales at which land-use scenarios can be applied, participants at the workshop considered the utility of addressing development of U.S. national land-use scenarios within an architecture that bridges multiple scales and modeling methods. Under a nested architecture approach, amounts of land use at the local to regional scales can be driven by the broader social and economic forces represented at the coarser scales, yet spatially allocated to finer resolutions, and using classification schemes that are best suited to a given question or purpose.

\section{Conclusions and possible next steps}

The final section of the report synthesizes options for catalyzing a nationally coordinated LULC development process. For the final break-out and plenary discussions, participants were asked to identify short- (2 years) and long-term (4-5 year) priorities to advance development of nationally-coordinated LULC scenarios. It was recognized that it would not be possible to satisfy all needs.

Short-term initiatives could focus on: evaluating prior experience and convening additional targeted workshops to develop an interagency scenario process; developing a nationally comprehensive inventory of existing LULC resources; developing best practices guidance for county/regional levels on developing/applying land-use/land-cover information; and encourage pilot studies, creating test-beds, and providing real world examples for sub-regional LULC scenarios that are embedded in larger frameworks. Connecting different methodologies for scenarios and identifying good practices and resources available for using information at different scales will be a valuable first step making best use of available resources. Immediate tasks could include regional and sectoral workshops or other activities to deepen understanding of user needs and the ability of existing resources to meet them, and compilation of a comprehensive LULC data inventory and dissemination of the results through a portal. Regarding development of the scenarios themselves, the agencies could jointly or individually commission or sponsor competitions to create individual scenario products. Making these products useful and of high quality would be premised on the near-term efforts to connect federal program managers, users, and the different research communities that need to be engaged.

The long-term priorities for scenario development identified included: developing a 'light touch' or 'thin' national framework approach that would promote consistency in assumptions and data and would provide a better foundation to develop national-scale, regionally differentiated, and spatially explicit LULC scenarios; advancing efforts to link models across sectors and scales; conducting research to improve representation of multi-scale processes that account for teleconnections and complex networks that could affect both land-cover and land-use dynamics; 
connecting scenario user and developer groups; and developing and implementing a protocol for mapping land use in a nationally consistent manner. The major benefits to the envisioned 'light touch' architecture are that it would allow users to develop sectorally or spatially nested scenarios that would be consistent with the national set, and that could be tailored to more specific needs. Importantly, this approach will require adequate regional input to be effective. In order to be most useful in the long run, the development of national scenarios (and supporting research) should be considered as an on-going process that encourages methodological pluralism and innovation. 


\section{Introduction: Land-use and land-cover scenarios and their uses}

Land use and land cover (LULC) are intricately linked with human societies that depend on the goods and services they provide. Land cover is the directly observable biological and physical characteristics of the land surface (e.g., forests, croplands, built-up areas) that interact with myriad Earth system processes, like hydrology, ecosystem function, and land-atmosphere interactions. Changes in land cover play a fundamental role in the Earth system, regulating biogeochemical flows of carbon, nitrogen, and other nutrients, and influencing climate and physical hydrology directly through characteristics such as albedo (surface reflectivity) and permeability (penetrability of water to layers below the surface). Land use, on the other hand, refers to the economic, social, and cultural purposes to which land is employed to support the various needs of human societies (e.g., food, shelter, and inputs to industrial processes). LULC changes play a substantial role in shaping the future availability and quality of natural resources and human well-being. LULC changes affect and are affected by climate, regional economics, technology development, population and migration, food and fiber production, water quantity and quality, and other factors, both human and natural.

Given the importance of LULC in many environmental and socioeconomic processes, and the fundamental uncertainties that exist about future LULC patterns, 'scenarios' of future LULC transitions and states are needed for both scientific enquiry and resource stewardship. Scenarios are descriptions of plausible futures and are used to facilitate planning to meet potential contingencies, for example by military strategists to develop plans to meet potential threats. Scenarios can be narrative or quantified (or both), with the narrative describing the overall trends and logic of future events in an internally consistent fashion, and the quantitative component exploring the consequences of these trends using numerical models. In global change science, scenarios are needed to make assumptions about future socioeconomic conditions, such as population growth, long-term economic development pathways, and potential energy technologies, both to consider potential impacts of human activities on the Earth system, as well as the context for adaptive responses to environmental change. These scenarios are used to 'drive' or 'force' LULC, climate, and Earth system models for research purposes and to produce climate scenarios of future patterns of temperature, precipitation, and other variables that could plausibly arise as a result of interactions of natural climate variability and human activities. Scenarios of future environmental conditions, such as sea level, water availability, ecosystem shifts, and other conditions also use climate and socioeconomic scenarios as inputs and are needed to plan for the potential impacts of global environmental change (see Parson et al. 2007, for an overview of the use of scenarios in global change research, and Moss et al. 2010 for a description of the current 'parallel' process of producing and using scenarios in climate change research).

Here, we use the term 'scenarios' to connote plausible futures that do not convey the likelihood or probability that the events described in the scenario will happen. Figure 1 arrays a variety of methods for thinking about the implications of the future depending on their degree of plausibility/likelihood and comprehensiveness. Thus, scenarios are distinct from 'predictions' or 'forecasts.' Even though they are not predictive, scenarios are based on analysis of historical and current conditions, both natural (such as climate or land cover) and socioeconomic (such as 
migration patterns, land use, or past rates of technological change). The term 'projection' is depicted in Figure 1 as straddling the boundary between futures with and without attributed likelihoods because it is used in the literature both with and without associated probabilities. The term is used in this report to describe the quantitative components of scenarios- which do not have associated probabilities. While they are useful analytic devices, there are also potential pitfalls in using scenarios, such as becoming overconfident that a specific scenario will occur and focusing on central tendencies or a business-as-usual future, instead of surprises or extremes in the tail of a distribution outcomes (Morgan and Keith 2008). Table 1 provides a summary of key definitions reviewed in this section.

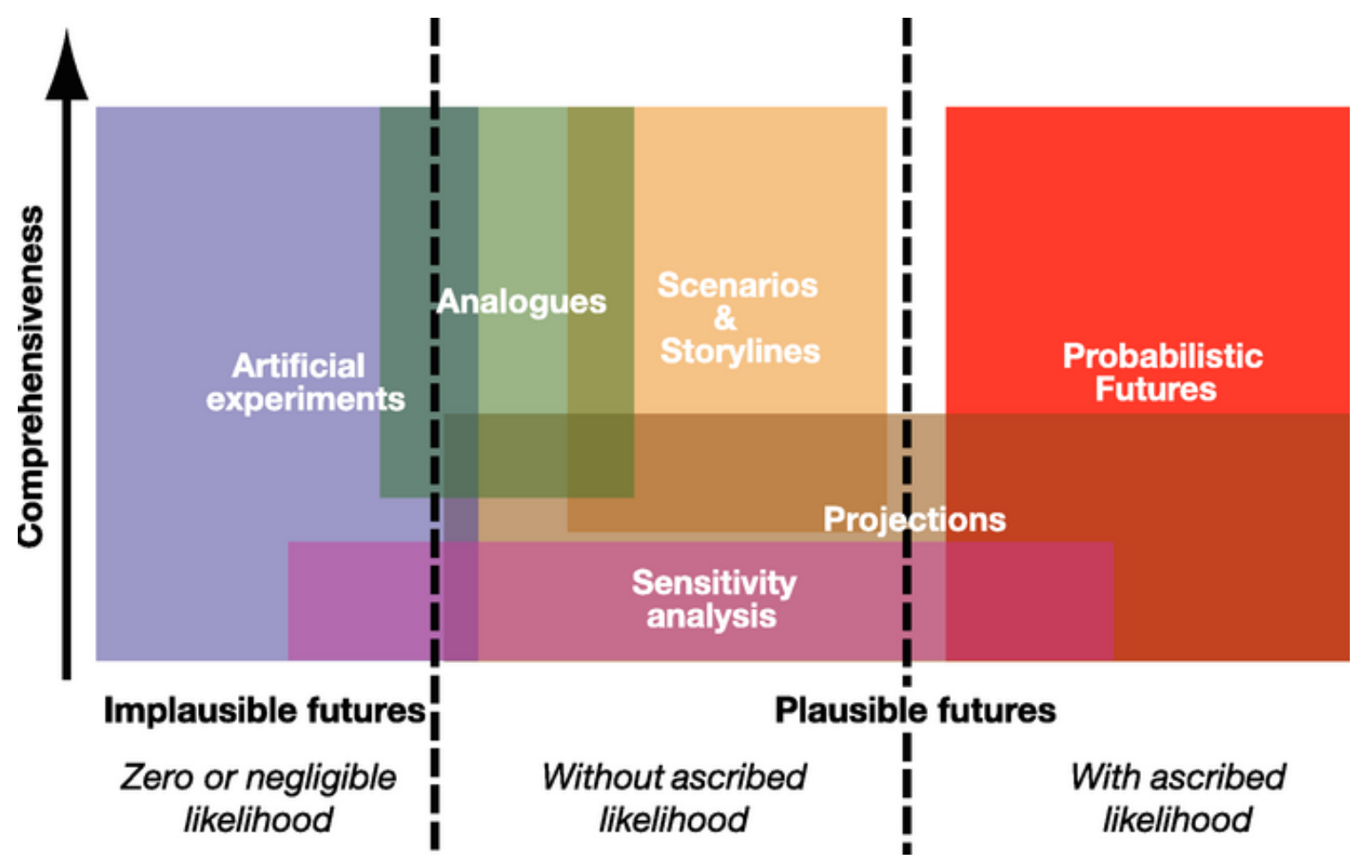

Figure 1: Relationship of scenarios to other ways of thinking about the future

Figure Source: Carter, T. R., R. N. Jones, X. Lu, S. Bhadwal, C. Conde, L. O. Mearns, B. C. O’Neill, M. D. A. Rounsevell and M. B. Zurek, 2007: New Assessment Methods and the Characterisation of Future Conditions. Climate Change 2007: Impacts, Adaptation and Vulnerability. Contribution of Working Group II to the Fourth Assessment Report of the Intergovernmental Panel on Climate Change, M. L. Parry, O. F. Canziani, J. P. Palutikof, P. J. van der Linden and C. E. Hanson, Eds., Cambridge University Press, Cambridge, UK, 133-171. 
Table 1: Core definitions

\begin{tabular}{|c|c|}
\hline Prediction/Forecast & $\begin{array}{l}\text { An estimate of actual evaluation of the future based on initial conditions. } \\
\text { Because of uncertainties, predictions/forecasts are usually probabilistic in } \\
\text { nature. }\end{array}$ \\
\hline Projection & Simulated response of a system to potential assumptions of future conditions \\
\hline Land cover & $\begin{array}{l}\text { Directly observable biological and physical characteristics of the land surface } \\
\text { (e.g., forests, croplands, built-up areas) }\end{array}$ \\
\hline Land use & $\begin{array}{l}\text { Economic, social, and cultural purposes to which land is employed to support } \\
\text { the various needs of human societies (e.g., food, shelter, and inputs to industrial } \\
\text { processes) }\end{array}$ \\
\hline Scenario & $\begin{array}{l}\text { Plausible descriptions of how the future might unfold in several key areas: } \\
\text { socioeconomic, technological and environmental conditions, emissions of } \\
\text { greenhouse gases and aerosols, and climate. Scenarios do not convey the } \\
\text { likelihood or probability that the events described will occur. }\end{array}$ \\
\hline
\end{tabular}

LULC scenarios are key to exploring scientific uncertainties related to interacting changes in the carbon cycle, hydrologic processes, and climate, and are thus needed as input to research sponsored by U.S. Global Change Research Program (USGCRP) agencies and coordinated through interagency working groups (e.g., modeling, adaptation science, carbon cycle). In addition, a number of federal agencies require LULC scenarios to support their individual research and management missions, including their use in carbon accounting, greenhouse gas (GHG) reporting, biomass and bioenergy assessments, hydrologic function assessments, fire and fuels planning and management, public health assessments, biodiversity and ecosystem services assessments, economic development activities, and forest and rangeland health assessments. LULC scenarios are thus useful to program managers, resource planners, and even private corporations and citizens confronting the need to consider changing environmental conditions in analyses of investments and management options. Finally, USGCRP is evaluating needs for the sustained assessment process ${ }^{1}$ proposed by the National Climate Assessment (NCA) Development and Advisory Committee (Buizer et al. 2013) and future assessment reports. A consistent set of scenarios, including those focused on LULC, are a key need expressed for this purpose.

In light of the importance of LULC scenarios for research and the potential advantage of developing a national and consistent set of scenarios for a wide range of potential uses, the Scenarios and Interpretive Science Coordinating Group (SISCG) of USGCRP convened a workshop on June 25-27, 2014 to explore the state of science of LULC and opportunities for producing LULC scenarios for the United States at a subnational scale. This workshop was intended to begin the development of an interagency process to identify critical uncertainties in projecting long-term (i.e., out to 2100) changes in land use/land cover; consider observational data and modeling capabilities to produce such long-term projections; and evaluate appropriate interpretive methods for the development of descriptive quantitative and qualitative scenarios of land-use/land-cover change that are, to the degree practical/possible, consistent with global-scale scenarios and/or models, and that can be used by federal agencies to support multiple needs. The workshop was structured to:

\footnotetext{
1 The Sustained Assessment is part of the 2012 USGCRP Strategic Plan (Goal 3).
} 
1. Identify key natural, physical, socioeconomic, and policy variables affecting LULC change.

2. Identify key gaps in data, modeling, and analysis capacity, etc. related to projecting LULC under a changing climate to inform future research needs.

3. Scope preliminary LULC change scenarios to gain insights into framing, contextual variations, methodological approaches, and paths forward for developing U.S. LULC change scenarios that can be applied to federal assessments and land management needs.

The agenda, list of participants, and Science Steering Committee and Federal Coordinating Group members are included in appendices at the end of the report. ${ }^{2}$ This report briefly describes existing data, models, and scenarios, first for land cover and then for land use. While separating these types of scenarios is somewhat artificial and difficult, doing so is useful to call attention to the relative paucity and fragmentation of resources for research on land use. More detailed lists of available global and national data products and trajectories of land cover/land use are included in Appendices D-F. ${ }^{3}$ The report then discusses needs identified by workshop participants for producing national scenarios. The last sections of the report relate a number of options for addressing some of these needs and developing LULC data and scenarios that were raised at the workshop. No effort was made to reach a consensus or to develop formal recommendations. A draft of the report was reviewed by the workshop science steering committee to ensure consistency with the actual discussions.

As will be discussed more thoroughly below, many existing scenarios of LULC are developed to explore the implications of global trends and issues, for example the scenarios commissioned and approved by the Intergovernmental Panel on Climate Change (Special Report on Emissions Scenarios or SRES, Nakicenovic and Swart, eds. 2000) or those prepared for the Millennium Ecosystem Assessment (Carpenter et al., eds. 2005). Numerous specific case-based scenarios have also been developed in the context of individual communities, watersheds, and regions, often without consideration or connection to the processes of global scenario development described above. Research on global environmental processes, such as climate change, has progressed to the point where national-scale, regionally-differentiated, and spatially-explicit LULC scenarios for the United States are needed to improve projections of future climate conditions and bridge from global processes to regional and local decision making. A key challenge to developing a set of process-based land-use scenarios at the national scale is that this particular scale is too detailed for many existing global models and too large (and heterogeneous) for most process models developed at the local scale. While a limited number of nationallyoriented LULC scenarios have been prepared (U.S. EPA, 2009; Sohl et al. 2007), to date there has been no concerted effort to assess research or end-user needs, survey existing resources, organize collaborations, and develop needed data and models to produce LULC scenarios for the United States. Because of the varied scales at which variables influence land-use change, and the multiple scales at which land-use scenarios can be applied, participants at the workshop explored the utility of approaching development of U.S. national land-use scenarios within an architecture

\footnotetext{
2 Also, workshop presentations and other relevant information can be found at http://www.globalchange.gov/about/iwgs/scenarios-resources/workshop-presentations and http://www.globalchange.gov/about/iwgs/scenarios-resources.

${ }^{3}$ A comprehensive overview of land-cover/land-use products that was produced for this workshop can also be found at http://www.globalchange.gov/about/iwgs/scenarios-resources.
} 
that links or bridges multiple scales and modeling approaches. The scales and potential bridging mechanisms are described below.

\section{Defining user needs}

The workshop included a set of panel presentations followed by discussion of the needs of federal agencies. Table 2 captures some examples of these needs presented at the workshop. Other leading uses not covered in this table but which were mentioned in workshop panel and break-out discussions include LULC change scenarios to support biomass and bioenergy assessments, effects of energy development studies, and ecosystems management (e.g., habitat and species impacts). As aforementioned, many federal agencies are direct users of, or have a need for using, regional LULC scenarios (e.g., USDA, U.S. DOE, U.S. DOD). A few agencies have or are developing LULC scenarios (e.g., U.S. DOI Geological Survey and U.S. EPA, USDA FS), and other agencies, like NASA, do not directly support development of LULC scenarios, but have numerous programs that fund foundational research that informs scenarios development.

All of the agencies at the workshop indicated a desire to have finer scale scenarios both temporally and spatially. The majority expressed an interest in 10 to 50 years and several mentioned the need for county-level projections. At the EPA Mid-Atlantic regional office, for example, most land-use decisions are made in 10-year increments. The office currently does not have access to models or LULC data that cover this region, and often also work with county governments to explore how information can be used and adapted to local conditions. A number of agencies are also interested in incorporating other major global change drivers, particularly climate change, in LULC projections. Another commonly held view among federal agency users of LULC scenarios was the need for better descriptions of available LULC data and scenarios, along with technical guidelines on their use.

Given the breadth and extent of interests, there is an opportunity for the agencies to continue refining their definition of needs in order to provide more detailed specification of the desirable characteristics of national-scale, regionally differentiated, and spatially-explicit LULC scenarios, for example with respect to the key uncertainties that should be explored, and the spatial and temporal resolution of needed variables. Among topics that require further consideration are the relationship of narrative and quantitative elements, and the extent to which it is useful and possible to nest U.S. scenarios within the globally-oriented scenarios being developed within the parallel (i.e., Representative Concentration Pathways or RCPs) scenario process (Moss et al., 2010). The view was expressed that it would be valuable to do so at a minimum to take advantage of climate scenarios produced using the RCPs as part of the Coupled Model Intercomparison Process $5^{\text {th }}$ phase (CMIP5), but that it was less clear that new socioeconomic scenarios (i.e., Shared Socioeconomic Pathways or SSPs) provided a relevant framework. It was recognized that it would not be possible to satisfy all needs, but that nonetheless a positive development from interagency cooperation on LULC scenarios could be a 'light touch' or 'thin' national framework that would promote consistency in assumptions and data used across a range of activities and assessments, but that would still allow users to develop sectorally- or spatiallynested scenarios that would be consistent with the national set and tailored to their more specific needs. 
Table 2: Examples of federal agency needs for LULC scenarios

\begin{tabular}{|c|c|c|c|c|c|}
\hline User & Use & $\begin{array}{c}\text { Temporal Scale } \\
\text { of Interest }\end{array}$ & $\begin{array}{c}\text { Spatial Scale of } \\
\text { Interest }\end{array}$ & Resources Used Currently & Specific Needs \\
\hline $\begin{array}{l}\text { USDA } \\
\text { Economic } \\
\text { Research } \\
\text { Service }\end{array}$ & $\begin{array}{l}\text { Assessment of: } \\
\text { - } \quad \text { National and } \\
\text { regional land-use } \\
\text { trends (Major Land } \\
\text { Uses Report) } \\
\text { - Environmental } \\
\text { impacts (erosion, } \\
\text { water quality, } \\
\text { carbon stock } \\
\text { changes, } \\
\text { effectiveness/distrib } \\
\text { ution of } \\
\text { conservation } \\
\text { practices) } \\
\text { Farm practices/crop } \\
\text { choice } \\
\text { Market access }\end{array}$ & $\begin{array}{l}\text { Annual/decadal } \\
\text { (including } \\
\text { reconstructions of } \\
\text { past LULC } \\
\text { change, as } \\
\text { practical) }\end{array}$ & $\begin{array}{l}\text { County, and } \\
\text { field- and farm- } \\
\text { levels }\end{array}$ & $\begin{array}{ll}\text { - } & \text { Census of Agriculture } \\
\text { - } & \text { National Land Cover Dataset } \\
\text { - } & \text { Cropland Data Layer } \\
\text { - } & \text { National Resources Inventory } \\
\text { - } & \text { June Area Survey } \\
\text { - } & \text { Agricultural Resource } \\
\text { - } & \text { Fanagement Survey } \\
\text { - } & \text { Sorest Inventory and Analysis } \\
& \text { Soil Survey Geographic database }\end{array}$ & $\begin{array}{l}\text { Products that will help } \\
\text { understand: } \\
\text { - } \quad \text { History/fate of agricultural } \\
\text { land } \\
\text { - } \quad \text { Urbanization } \\
\text { - } \quad \text { Access to water } \\
\text { - } \quad \text { Access to markets (producers } \\
\text { - } \text { and consumers) } \\
\text { - } \quad \text { rates } \\
\text { - } \quad \text { Technorsion costs, hurdle } \\
\text { - }\end{array}$ \\
\hline $\begin{array}{l}\text { USDA Forest } \\
\text { Service }\end{array}$ & $\begin{array}{l}\text { Produces projections of } \\
\text { major land uses for the } \\
\text { decadal Resources } \\
\text { Planning Act (RPA) } \\
\text { Assessment }\end{array}$ & 50 years & $\begin{array}{l}\text { County, but } \\
\text { want to use } \\
\text { equal-area grids } \\
\text { to account for } \\
\text { variation in } \\
\text { county size }\end{array}$ & $\begin{array}{l}\text { - } \\
\text { andCD for landscape pattern } \\
\text { - } \quad \text { NRI for land-use projections } \\
\text { - For } 2010 \text { RPA Assessment: } \\
\text { Intergovernmental Panel on } \\
\text { Climate Change (IPCC) SRES } \\
\text { for population and economic } \\
\text { assumptions } \\
\text { - For 2020 RPA Assessment: } \\
\text { looking to IPCC Fifth } \\
\text { Assessment Report results }\end{array}$ & $\begin{array}{l}\text { - LULC change nest within } \\
\text { integrated scenarios that } \\
\text { reflect changes in } \\
\text { demographics, economy, } \\
\text { technology, institutions, } \\
\text { policy and climate } \\
\text { National level projections by } \\
\text { major land-use/cover classes } \\
\text { that include quantitative } \\
\text { linkages to other variables } \\
\text { that can be linked to more } \\
\text { spatially disaggregated } \\
\text { analysis. } \\
\text { Options for land-use data } \\
\text { besides the NRI }\end{array}$ \\
\hline
\end{tabular}


Table 2: Examples of federal agency needs for LULC scenarios (cont'd)

\begin{tabular}{|c|c|c|c|c|c|}
\hline User & Use & $\begin{array}{l}\text { Temporal Scale } \\
\text { of Interest }\end{array}$ & $\begin{array}{l}\text { Spatial Scale of } \\
\text { Interest }\end{array}$ & Resources Used Currently & Specific Needs \\
\hline U.S. DOD & $\begin{array}{l}\text { Understand predicted } \\
\text { and plausible population } \\
\text { growth trends and their } \\
\text { associated effects on } \\
\text { land conversion and use } \\
\text { for geographic areas } \\
\text { surrounding installations } \\
\text { and ranges and } \\
\text { underlying training air } \\
\text { space. }\end{array}$ & $\begin{array}{l}<20 \text { years } \\
\text { (predictions) } ; 20- \\
50 \text { years and } 50+ \\
\text { years (scenarios) }\end{array}$ & $\begin{array}{l}\text { Landscape/ } \\
\text { regional scales } \\
\text { (Sentinel } \\
\text { landscapes), } \\
\text { and adaptable } \\
\text { grid } \\
\text { predictions/ } \\
\text { scenarios of } \\
\text { "growth" that } \\
\text { correspond to } \\
\text { development } \\
\text { (land use) } \\
\text { changes. }\end{array}$ & $\begin{array}{l}\text { Predicted population growth trends } \\
\text { (including population density and land } \\
\text { use) }\end{array}$ & $\begin{array}{l}\text { Short-term: Best practices for } \\
\text { County-level predictions and } \\
\text { scenarios of population growth } \\
\text { and associated changes in land } \\
\text { conversion and use } \\
\text { Long-term: Adaptive grid } \\
\text { approach for providing relevant } \\
\text { population growth and land } \\
\text { conversion/use } \\
\text { predictions/scenarios at the } \\
\text { "right" spatial scale }\end{array}$ \\
\hline $\begin{array}{l}\text { U.S. DOI } \\
\text { Geological } \\
\text { Survey, } \\
\text { Earth } \\
\text { Resources } \\
\text { Observation } \\
\text { Systems }\end{array}$ & $\begin{array}{l}\text { Produces LULC change } \\
\text { projections for a variety } \\
\text { of applications (carbon, } \\
\text { climate, biodiversity and } \\
\text { hydrologic) and works } \\
\text { with multiple users. }\end{array}$ & $\begin{array}{l}\text { Different temporal } \\
\text { scales } \\
\text { (traditionally } \\
\text { produce } 50-100 \\
\text { year projections) }\end{array}$ & $\begin{array}{l}\text { Different spatial } \\
\text { scales } \\
\text { (traditionally } \\
\text { produce } 250-\mathrm{m} \\
\text { spatial } \\
\text { resolution } \\
\text { projections) }\end{array}$ & $\begin{array}{l}\text { Examples are: } \\
\text { - } \quad \text { County-based data from RPA } \\
\text { Assessment (Wear et al.) } \\
\text { - } \quad \text { Radeloff et al. data for the } \\
\text { conterminous U.S. } \\
\text { - Their FORE-SCE projections for } \\
\text { the conterminous U.S. }\end{array}$ & $\begin{array}{l}\text { Modeling structure that can assess } \\
\text { all components of the landscape, } \\
\text { including anthropogenic (land } \\
\text { use) change and "natural" change } \\
\text { (vegetation succession, fire, } \\
\text { climate-induced vegetation shifts, } \\
\text { etc.) at different spatial, thematic } \\
\text { and temporal resolutions (to } \\
\text { increase flexibility of their } \\
\text { modeling tool) }\end{array}$ \\
\hline $\begin{array}{l}\text { U.S. EPA, } \\
\text { Office of Air } \\
\text { Quality } \\
\text { Planning and } \\
\text { Standards }\end{array}$ & $\begin{array}{l}\text { Projections of location } \\
\text { of air emissions and } \\
\text { level of economic } \\
\text { activity in those } \\
\text { locations to analyze the } \\
\text { impacts of air quality } \\
\text { regulations }\end{array}$ & 20 years & $\begin{array}{l}\text { Local, regional, } \\
\text { national and } \\
\text { global } \\
\text { (depending on } \\
\text { pollutant and } \\
\text { emission } \\
\text { source) }\end{array}$ & IPCC SRES & $\begin{array}{l}\text { Scenarios that will help inform } \\
\text { questions such as: } \\
\text { - Where will populations be? } \\
\text { Where will major industrial } \\
\text { and commercial sources of air } \\
\text { emissions be? } \\
\text { Will climate change have } \\
\text { impacts on the future location } \\
\text { of people and their local } \\
\text { economies? }\end{array}$ \\
\hline
\end{tabular}


Table 2: Examples of federal agency needs for LULC scenarios (cont'd)

\begin{tabular}{|c|c|c|c|c|c|}
\hline User & Use & $\begin{array}{l}\text { Temporal Scale } \\
\text { of Interest }\end{array}$ & $\begin{array}{l}\text { Spatial Scale of } \\
\text { Interest }\end{array}$ & Resources Used Currently & Specific Needs \\
\hline $\begin{array}{l}\text { U.S. EPA, } \\
\text { Mid-Atlantic } \\
\text { Office (also } \\
\text { input from } \\
\text { other } \\
\text { regional } \\
\text { offices) }\end{array}$ & $\begin{array}{l}\text { For decision-making; } \\
\text { primary use of } \\
\text { scenarios: as inputs to } \\
\text { models on impacts of } \\
\text { natural resources and } \\
\text { human health }\end{array}$ & $\begin{array}{l}\text { Both long-term } \\
\text { (50-100 years) } \\
\text { and decadal }\end{array}$ & $\begin{array}{l}10-30 \text { meter } \\
\text { resolution; } \\
\text { projections of } \\
\text { landscape } \\
\text { change accurate } \\
\text { at about a } \\
\text { square mile }\end{array}$ & $\begin{array}{l}\text { - Land use } 40 \text { year projections } \\
\text { developed by the } 2001 \text { Mid- } \\
\text { Atlantic Integrated Assessment } \\
\text { for } 2010 \text { regional prioritization } \\
\text { exercise } \\
10 \mathrm{~m} \text { projections of mountain top } \\
\text { mining development in coal } \\
\text { region of WV } \\
\text { Chesapeake Bay Land Cover } \\
\text { Data Series (30 sq. m. raster cell } \\
\text { size) based on NLCD 2001, and } \\
\text { 2001 and 2006 Landsat imagery } \\
\text { Course scale econometric-based } \\
\text { projections of land change as } \\
\text { input to Chesapeake land change } \\
\text { model }\end{array}$ & $\begin{array}{l}\text { Scenarios to help inform on-the- } \\
\text { ground decisions. Ideally, } \\
\text { scenarios would: } \\
\text { - Link to global climate } \\
\text { scenarios and demographic } \\
\text { projections } \\
\text { - Project change in all types of } \\
\text { land use (forest to mining, } \\
\text { agriculture to forest) and } \\
\text { urban growth and } \\
\text { intensification } \\
\text { Allow end user to explore } \\
\text { effects of new policies or } \\
\text { regulations } \\
\text { - Help predict impacts to } \\
\text { landscape structure and } \\
\text { composition } \\
\text { A nationally consistent } \\
\text { product that can be used as } \\
\text { is or could be refined based } \\
\text { on consistent and mutually } \\
\text { acceptable approaches, and } \\
\text { which contains } \\
\text { detail/guidance that will } \\
\text { prevent misuse of } \\
\text { information by users like the } \\
\text { regional offices }\end{array}$ \\
\hline $\begin{array}{l}\text { USGCRP, } \\
\text { NCA }\end{array}$ & $\begin{array}{ll}\text { - } & \text { Facilitate } \\
\text { assessments and } \\
\text { planning } \\
\text { - } \\
\text { Develop consistent } \\
\text { outlooks across } \\
\text { scales }\end{array}$ & $\begin{array}{l}\text { Subsequent } 25- \\
100 \text { years }\end{array}$ & $\begin{array}{l}\text { State- to local- } \\
\text { levels }\end{array}$ & $\begin{array}{l}\text { CMIP3 and NARCCAP data with A2 } \\
\text { and B1 IPCC SRES }\end{array}$ & $\begin{array}{l}\text { Embedding scenario } \\
\text { information into Federal } \\
\text { agency activities } \\
\text { - } \quad \text { RCP/SSP development for } \\
\text { U.S. } \\
\text { - Coordinating efforts of } \\
\text { agencies }\end{array}$ \\
\hline
\end{tabular}


A gap identified at the workshop was the need to better link to regional users and providers of LULC data and scenarios. Given that LULC data and scenarios were provided as part of the recently-completed NCA process, it was suggested that an important source of information on regional uses of these products could be some combination of workshops, a survey, or in-depth interviews of potential users, probing uses of existing resources as well as unfulfilled requirements and needs. This was seen as an important potential contribution to developing scenarios to support the sustained assessment process.

The report now turns to a brief overview of existing and emerging LULC resources that were discussed during presentations and discussions at the workshop. This is not an exhaustive catalog but rather a discussion of resources mentioned by participants that suggests the types of materials and approaches that are available to respond to the needs identified above. Another requirement, which will be discussed further below, is an effort to develop a nationally-comprehensive virtual 'collection' of LULC resources, focusing in particular on land use.

\section{Land cover: existing and emerging data sets, models, and scenarios}

The need and operational capabilities for collecting land-cover data are well established in the Earth observation community, for example through identification of land cover as an essential climate variable and regular production of the National Land Cover Dataset (NLCD). Existing global LULC data sets are mostly gridded products obtained from remote sensing data. The first generation of gridded products, such as the International Geosphere Biosphere Programme Land Cover Classification, were based on coarse resolution sensors (larger than $1 \mathrm{~km}$ ). The spatial resolution of these LULC datasets has increased over the years, from $\geq 1 \mathrm{~km}$ (Loveland et al., 2000; Bartholome et al., 2002) in the early 2000's, to a new generation of moderate and coarse $(<1 \mathrm{~km})$ land-cover products. These datasets included the MERIS-based GlobCover 2005 and GlobCover 2009 and the several collections of thematic MODIS products. In the last few years, the increase in the number of medium-resolution sensors $(\sim 30 \mathrm{~m})$ and growing computer power has resulted in the first global medium resolution datasets: Landsat Tree Cover Continuous Fields (Sexton et al., 2013), Global Forest Change (Hansen et al., 2013), and Finer Resolution Observation and Monitoring of Global Land Cover (Gong et al., 2013).

At the national level, several U.S. agencies and institutions have generated thematic products to serve their missions. These products comprise gridded datasets, surveys and products combining both. The gridded land-cover products, mainly based on Landsat imagery, generate present and historical LULC information (e.g. National Land Cover Database, Land cover Trends, Landscape Fire and Resource Management Planning Tools Project or LANDFIRE, National Agricultural Statistics Service - Cropland Data Layer, Woods Hole Research Center-National Biomass and Carbon Dataset for the year 2000, USDA-USFS Forest Biomass).

Because remote sensing is a main source of land-cover products, classification systems are limited by the characteristics of the remote sensing system used to generate the products. These land-cover products are often not consistent and present limited interoperability. This is particularly evident in global datasets, with classification systems of varying complexity in which the lack of thematic coherence often prevents the comparison and integration of products. 
Active sensors such as LiDAR are already providing 3-D information about land surfaces and allow the capture of previously poorly quantified variables (biomass, building density) and a more precise representation of land surfaces. Already planned hyperspectral sensors will provide the capabilities for a direct measurement of biophysical variables and the quantification of chemical components of the vegetation. Additionally, the increasing number of medium resolution imagery (DMC, IRS-LISS III, SPOT, Sentinel 2) and the integration of information from multiple sensors shows potential to improve the temporal resolution of the images and reduce the negative impact of cloud coverage on quality. This new reality is likely to foster the development of more advanced information extraction techniques to exploit the increase in spatial and temporal resolution (object-based image processing, time series statistical modeling).

A recent review categorized land change modeling approaches into five basic types, roughly arrayed on a gradient from more empirically-oriented models focused on projections to more process-oriented models focused on representing the causal mechanisms of change (NRC 2013). The more empirically-oriented approaches tend to be applied in situations rich in spatial data, but poorer in theory about processes. For that reason, they tend to be used to model land cover, whereas the more process-oriented approaches tend to be used for modeling land use (as described in the next section).

Products providing land-cover projections are scarce. Such products are commonly built using hybrid land-change models, commonly fit to historical data. National-scale products are often limited by the lack of consistent and reliable historic information, and are often focused on single sectors or land covers (e.g. impervious surfaces). Projecting future trajectories will require a better and more integrated understanding of processes linking policy frameworks, human behavior, and land-use change. Land-cover projections should also benefit from an improved understanding and representation of multi-scale processes that account for tele-connections and complex networks that could affect both land-cover and land-use dynamics. Furthermore fully dynamic land-cover models coupled with other Earth system models should enhance capacity to understand and project direct and indirect effects between different sectors.

Land-cover forecasts have two primary components: 1) an estimate of the amount of land that is required for each land cover over some area and 2) a spatial allocation of land cover within that area. Machine learning and statistical approaches (like Land Transformation Model or LTM, Pijanowski et al. 2002 and GEOMOD, Pontius and Malanson 2005) are generally used to spatially allocate amounts of each land type given from another model or scenario, based on relationships of observed land covers or land-cover changes with spatial variables that, based on geographic and economic theory, might be expected to affect suitability for different covers. Predictions about future spatial allocations of land cover are based strongly on observed patterns of allocation in the past. Cellular approaches (Conversion of Land Use and its Effects or CLUE (Verburg et al. 2002), Dinamica (Soares-Filho et al. 2006), and SLEUTH (Clarke and Gaydos 1998)) also focus on allocation spatial patterns by combining information about suitability with information about trends in demand and neighborhood interactions to simulate future land-cover patterns. They can include some element of bottom-up effects on amounts of land-cover demand in a given area and can include feedbacks in the allocation process, through iterative assignment and adjustment. 
Because future changes in land cover are likely to arise from processes in both the biophysical (e.g., climate and natural disturbance) and human (e.g., price and demand for food, urbanization) systems, future land-cover patterns need to be necessarily linked with land use. At global scales, land models, such as the Community Land Model (CLM), have sought to link changes in the land surface with a variety of Earth system processes, but have used an approach that treats land cover as potential natural vegetation that responds to ecosystem process drivers, without consideration of the effects of human activities on the land surface. Incorporating human landcover-change and land-management processes into models of this sort is an on-going top research priority. Recent studies (e.g., Jones et al. 2013; Davies-Barnard et al. 2014) have used land-use scenarios based on the RCPs as inputs to Earth system models which house global land models, such as the Community Earth System Model and Hadley Centre Global Environment Model version 3. For the United States, the U.S. Geological Survey is applying the Forecasting Scenarios of Land-use Change (FORE-SCE) model to develop land-cover scenarios in support of their national land carbon assessment activities. By translating Intergovernmental Panel on Climate Change (IPCC) SRES scenarios to demands for land in different uses, they were able to link simulated land-cover changes to these qualitative storylines. Similarly, scenarios of change in impervious surface were linked to SRES scenarios using Integrated Climate and Land Use Scenarios or ICLUS (Bierwagen et al. 2010), which empirically relates land use (i.e., housing density) to impervious surface density.

\section{Land use: existing and emerging data sets, models, and scenarios}

In the United States, several federal agencies have responsibility for collecting land-use-related information, including USDA (through its Natural Resources Inventory, Census of Agriculture, and Cropland Data Layer projects) and U.S. Census (through its Censuses of Housing, Population, and Businesses). Local jurisdictions frequently keep land-use information at the level of individual tax parcels, though the coverage and formatting of these data is quite inconsistent. While well suited to extract information on land cover, remote sensing has important shortcomings in its ability to produce information on land use and land management, principally the spatial and temporal resolution of existing remote sensing sensors limit their usefulness for this purpose. Coarse and moderate resolution sensors have been limited in their ability to provide information at the sub-pixel levels at which relevant land management decisions are often implemented.

Advances in time series analysis of moderate-resolution remote sensing data will potentially improve the remote sensing-based characterization of land surfaces, allowing the detection of features directly associated with management practices. Promising results for the characterization of land-cover changes that are indicative of changes in land use and land management at selected study sites (e.g., Maxwell and Sylvester 2012; Sexton et al. 2013; Wilson and Brown 2014), show that the problems associated with frequent cloud coverage can be overcome and land-use-relevant information extracted from these image series. Ultimately, high-quality information about land use will require integration of data from a variety of sources, including remote sensing, ground surveys, and social and economic data of various kinds. The importance of availability of land-use data as a key gap was identified in the workshop (and is described in Section 5). Possible innovations discussed at the workshop that can help fill this gap are discussed in Section 7. 
Research on the drivers and processes of land-use change has been key to developing models that can project future land-use patterns under alternative assumptions of socioeconomic and environmental conditions. This research has been carried out, often separately, for different sectors (e.g., urban, agriculture, and forestry) and at different scales. Land-use patterns are affected by both top-down influences, for example through the global commodity markets that affect prices for different crops, and bottom-up influences, for example through the choices and interactions of individual farmers and other land users or managers that affect local land-use conditions and potentials. They are also affected by social, economic, and environmental factors that alter the land-use and land-management choices of the myriad actors in the land system. A challenge in developing scenarios is to deploy models that bridge these different traditions and scales, in order to account for the interactions and teleconnections that affect land-use choices at any given place.

The models used to project land-use changes are based on empirical and theoretical research on land-use outcomes and drivers. Rather than review decades of land-use research in the different sectors that influence land use, we provide below a (somewhat subjective) schematic summary of the outcomes and drivers that have been used to describe land-use change in the different sectors (Table 3). Underlying research in all of these sectors are conceptual models that describe the decision-making processes that people use in making choices about land. The economic theory of land rent, from earlier work of von Thünen, Ricardo, and Alonso, provides the theoretical foundation for much of the work, though demographic changes affecting labor supply and composition play an important role as well. The economic theories provide a basis for describing how economic actors decide among alternative choices, e.g., whether to plant corn or wheat or whether to move to the city center or the outskirts, based on some description of economic returns. Labor supply and composition can act as a constraint on optimal allocation of land uses. For example, the spatial-mismatch hypothesis is an argument of constrained growth in the U.S. economy since the great recession due to reduced mobility.

Table 3: Schematic summary of the land-use outcomes and drivers included in empirical and modeling work within different sectors

\begin{tabular}{|llll|}
\hline \multirow{2}{*}{$\begin{array}{l}\text { Outcomes } \\
\text { of interest }\end{array}$} & Arban & Agriculture & Forestry \\
& Types of development & Rates of clearing, plowing, & Rates of clearing \\
& Patterns of development & and abandonment & Rotation schedules \\
& Type of land converted & Frop mix & Species mix \\
& Land planning & Farm size & Impacts on habitats and \\
& Decline and redevelopment & Nonpoint source pollution & Prodiversity \\
& Social and economic segregation & Total production & \\
& and inequality & & \\
\hline Drivers & Population growth & Soil productivity & In addition to those for \\
& Economic growth & Climate conditions and & agriculture: \\
& Transportation and & variability & Forest management \\
& communication technology and & Distance to markets & strategies \\
& cost & Prices and price & Stronger effect of \\
& Public vs. private ownership & fluctuations & discount rates \\
& Land planning & Local, regional and global & \\
& Natural amenities & demand & \\
& Social segregation and inequality & & \\
\hline
\end{tabular}


The modeling approaches described in the recent NRC (2013) report that tend to be used in modeling land use are those that have a richer structural representation of decision making by land owners and managers. Integrated Assessment Models such as Global Change Assessment Model or GCAM (Calvin et al. 2013) and Emissions Prediction and Policy Analysis or EPPA (Reilly et al. 2012)) focus on determining the amount of land in each land-use category based on computable general and partial equilibrium models, which account for demand and supply of commodities in different regions (15-150 regions globally, depending on model vintage), along with trade among those regions. Spatial allocation in these models is recalculated in each time step (15 to 1 years, depending on the question) after demands have been determined, so the allocation process does not assess bottom-up impacts on supply and demand. Emergent approaches that better integrate these global models with spatially disaggregated patterns are currently under development (Platform for Regional Integrated Modeling and Analysis or PRIMA, West et al. 2014; and Regional Integrated Assessment Model or RIAM, DOE, 2013). Spatially disaggregated econometric models (like those described by Irwin and Geoghegan (2001) and Lubowski et al. (2008)) tend to focus on the spatial allocation of land uses based on economic returns to different land uses, along with spatial interactions, but can also simultaneously determine amount of each land use, assuming the factors driving land-use choices in the future have the same effects that they did in the past. Agent-based models (like those described by Parker et al. (2003)) focus on understanding how individual decisions produce patterns of land allocation based on behavioral models and interactions among actors. These approaches offer opportunities to incorporate more explicit process representations that include the role of institutions and policies, adaptation and learning, technology adoption, and social interactions (Rounsevell et al. 2014), but existing models tend to be implemented for only local case studies, and work needs to proceed on scaling and generalizing both the conceptual (e.g., Magliocca et al. 2013) and computational underpinnings of these models.

National-level land-use scenarios have been both part of the output from global models (like GCAM) that link land use to global climate and economic changes, and at more disaggregate scales using spatial econometric models. In this latter category, Wear (2010) used an econometric model of land-use shares at the county level to estimate changes under population and economic growth scenarios consistent with the SRES scenarios. Also, Lawler et al. (2014) demonstrate an application of Lubowski et al.'s (2008) econometrically estimated land-use model to national level scenarios related to policy and commodity price changes into the future. Agent-based land-use models have not yet been developed that would support production of national-scale scenarios, but at finer scales, in local settings, and for specific sectors, they have been used to evaluate the implications of price, policy, and environmental changes on land-use responses and impacts (e.g., Sengupta et al. 2005; Robinson and Brown 2009; LigmannZielinska and Jankowski 2010).

\section{A Selection of Gaps and Challenges}

\section{Inconsistent data ontologies}

A gap identified in a number of comments in plenary sessions and breakout groups is the inadequacy of comprehensive and coherent data needed to improve research on a number of 
critical issues. As one participant noted (paraphrased), 'there's a reason we get such a range of answers about whether forests are going to be a source or sink of carbon in the future - there are different data sets for both land cover and use that are not cross-referenced or compared in a meaningful way, and this provides a poor foundation for modeling.' Data sets often do not match because of measurement and categorization issues. Different approaches to defining different LULC categories and ways of reporting data are part of the problem, for example categorical classification of grid cells to all one state or another, versus use of continuous variables to provide percentages of different covers or uses, in others. In fact, some participants argued that data harmonization was a larger problem than access. A number of barriers to developing common definitions and measurements were identified, including terms or categories defined in legislation or regulations that cannot be changed, differences in methods across disciplines, and differences in what makes sense at different scales. Developing dataset ontologies that would go beyond metadata to provide information on how to translate consistently across data sets was another idea discussed.

\section{Missing land-use data}

Collection of nationally comprehensive land-use data has not been coordinated in any meaningful way, so that our nation lacks a consistent, comprehensive, and coordinated land-use observational strategy (Theobald 2014). While NLCD has been essential in providing land-cover data and supporting various modeling and scenario studies, there remains a need for better data (and modeling frameworks) that directly link the human motivations and socio-economic processes that drive land-use change to the biophysical land-cover outcomes of land-related decision processes. Among the missing data mentioned were: land management actions and practices; laws and restrictions; ownership; structural characteristics; and pricing and income elasticity. It was argued that there were challenges in aggregating land-use data to obtain a comprehensive view of conditions associated with a particular parcel or area, for example associating population, income, land use, land management, and other factors. The development of nano satellites could enhance our potential for continuous monitoring of land surfaces at high spatial resolution and the establishment of systematic land-use observations programs. The integration of remote sensing-based products with field data, ground-based information, socioeconomic variables and alternative potential sources of LULC information such as crowdsourcing and data mining will open new possibilities to provide and update additional information on land use. At the national scale, there is a need for a ground-based system that combines several of these methods for data collection.

\section{Relating land cover and use}

Another challenge for research, modeling, and scenario development identified was relating land-cover and land-use data. Some argued that improving methods for spatially organizing landuse data would be extremely useful, for example data sets on land management practices, economic rents for different uses, co-located socioeconomic and biophysical data, and spatiallyexplicit information on legacy land uses. Participants noted opportunities and needs with respect to data held by both private sector organizations and government agencies at multiple scales (national, state, county, and municipality). 


\section{Model integration and modularity}

Another identified challenge to development of national LULC scenarios was the need to improve model coupling and integration. The recent National Research Council (NRC) report discusses different types of land-use models, but only hints at how they are being, and can be, integrated and provides no quantitative evaluation or comparison among the approaches. When confronted with a modeling challenge that seems to have been addressed in another type of model, it is often difficult to obtain the information that would enable a modeler to decide to pursue further information and collaboration. Because of the number of factors that drive LULC conversions, another challenge is developing flexible and modular frameworks capable of being adapted to the modeling or scenario challenge at hand. Considering cascading processes and drivers across multiple systems could require the ability to link a large number of complex models together. But there are disadvantages to this strategy, including consequences for the computational burden and the challenges of assessing uncertainty. Use of reduced form or surrogate models that represent relationships among selected variables in more complex and computationally-intensive models in simplified form is one approach for addressing this challenge, although knowledge and methods for developing surrogates needs to be advanced. Another approach is to provide inputs on factors such as global energy and crop prices, demographic change, and changes in climate that might affect relative levels of productivity on land from scenario narratives or from data sets based on outputs from other models. A different type of integration problem involves working across scales, for example models used at the federal level (e.g., Federal Emergency Management Agency's natural hazard loss estimation software, HAZUS) and models used to assess land or resource use conditions at local levels.

\section{Uncertainty in projections under non-stationary and non-equilibrium conditions}

Challenges associated with projecting complex systems were addressed at the workshop. Projections about future land-use and land-cover patterns involve assumptions about how the future might be expected to be different from the past and present, and what relationships or driving factors might be reasonably assumed to be unchanged in the future (i.e., stationary). For example, a model might assume that, now and in the future, places that are most productive for a particular agricultural commodity will be the first to be brought into production of that commodity and the last to be taken out of production. We also often assume in our empirical work that the observed land-use patterns are those reflective of current economic and environmental conditions, rather than some relic of past conditions (i.e., we assume land-use patterns are in equilibrium). However, when environmental or social conditions are changing (i.e., are non-stationary) or where feedbacks play a strong role in determining future amounts and patterns of LULC, uncertainties can be magnified. For example, it is a well-known phenomenon that existing patterns of urban development and economic activity can influence future job growth in a given sector and, therefore, land-use demands in that sector. Such positive feedbacks can have pernicious effects on our ability to project, because they can produce nonlinear behavior in models that can be very sensitive to both initial conditions and to random events. These characteristics of complex systems pose special challenges for the equilibrium assumption, such that a land-use process might produce multiple different equilibria, depending on the initial conditions, the existence of rare but consequential events, and the particular path a land-use system follows in its evolution. For that reason, it should be general practice to generate 
and examine the range of outcomes produced by any given process (and, by extension, model) of land-use change under different scenarios.

\section{Representing processes across scales}

As identified in the NRC (2013) report, linking land-change models across scales is a key challenge that will permit representation of the interactions among land-change patterns and processes at global, national, regional, and local scales. This need was reiterated, both in terms of the need for coordinated land-use and land-cover scenarios at multiple scales and the identification of processes of land-use change that play out at different scales. The way in which global and national scale dynamics in population, economics, climate, and other factors influence inter-regional dynamics in land demand within the U.S., and the way these dynamics play out differently in different regions and localities, argues for a modeling approach that takes on a nested structure. Such a nested structure does not currently exist for a national land-change modeling enterprise, but could allow for flexible implementation of qualitative and quantitative inputs and models at multiple scales, depending on the agency or regional requirements of a given application. Such a structure might be most effective if designed such that the specifications of assumptions, category definitions, and process interactions are only lightly detailed (i.e., a 'light-touch' structure), leaving further specification to a wide range of users. Designing a thin or light touch structure at the national scale does not prevent developing regional or sectoral scenarios that have strong coupling to the themes or quantification at the national scale. Zurek and Henrichs (2007) distinguish five levels of interconnected determined by the purpose (e.g., modeling, context setting for stakeholder processes) and issue being addressed.

The final sections of the report describe several potential options for addressing some of the gaps and opportunities identified at the workshop. Pursuit of some of these ideas by interested agencies, individually or in some cases collectively, could significantly advance the state of science of LULC research, modeling, and applications.

\section{Deepen understanding of suitability of current resources and user needs: regional and sectoral workshops and dialogue}

An issue raised in a number of break-out groups and plenary discussions is informing national LULC scenarios with more specific information on how users would like to make use of them and what issues they would like them to address. This was seen as being particularly important because it is frequently the regional (and finer) scale information on land use that is missing. Regional (or local) organizations will be helpful in identifying and integrating this information. Without adequate regional input, it seems less likely that a scenario framework that encourages light-touch national scale scenarios that can be used to inform development of more detailed regional scale scenarios tailored to user needs at that scale will be possible. Regional engagement was also discussed as potentially less likely to occur than engagement with stakeholders from various sectors, because while some agencies have sectoral responsibilities, none have responsibility for the regions. Participants discussed the need to better understand what user questions are at this scale: is it the probability of change in land use and/or land cover under different scenarios? Which transitions are of greatest interest: urban, non-urban, peri-urban? 
Across gradients of agro-forestry? And on what time scales? How well do regional users feel they have reliable present-day snapshots of land cover and land use? The suggestion was made to engage regional organizations including stakeholders working with federal activities such as the Regional Integrated Sciences and Assessment (RISA) programs and the Climate Science Centers in workshops, interviews, and/or surveys. A question was raised about whether to continue to use the NCA regions as a way to organize such an engagement effort. While these are not ideal from many perspectives, they do have advantages as well.

\section{Inventory and integration of existing and emerging resources: a national land cover/land use portal}

A number of existing data resources were identified in preparation for the workshop and in the recent NRC (2013) report and are available to support LULC scenarios and modeling. More commonly used data sources include: existing data on land cover and related variables collected both globally (e.g., GLOBCOVER, Global Forest Change (Hansen et al. 2013), MODIS Land Cover, Land-Cover Change, and Vegetation Continuous Fields) and nationally (e.g., NLCD LANDFIRE, U.S. Geological Survey Land Cover Trends, and National Biomass and Carbon Dataset); existing data on land use and related variables collected both globally (e.g., LANDSCAN global gridded population (Oak Ridge National Laboratory), and the HYDE and Global Land Use Model (GLM) data on croplands) and nationally (e.g., Census of Agriculture, National Resources Inventory, and Cropland Data Layer); and scenario-based projections at the global (e.g., from GLM, Millennium Ecosystem Assessment) and national (ICLUS and University of Wisconsin projections of housing density; USFS RPA assessment) levels. Additionally, new and potentially under-utilized resources could be marshalled to improve the data environment. These include public-use micro-sample (PUMS) data from the Census to provide data on population compositions, and a wide variety of derived variables (including market access, irrigation, accessibility, actual and potential net primary production, elevation, and more) that can support modeling.

Two key challenges for the LULC science and modeling communities are to (a) innovate on the types of data available and (b) work to better integrate and share existing data resources. A number of new opportunities for basic data collection have presented themselves in recent years. The area of volunteered geographic information (VGI) includes a wide range of intriguing, but relatively untested, approaches to collecting data by integrating mobile, internet, and social computing technologies to gather information from so-called "human sensors." This approach has been demonstrated in the Geo-Wiki project (geo-wiki.org) as a means for verification of land-cover classifications from remote sensing data. Surveys can be implemented on mobile devices to improve the cost of collecting social data (e.g., the iEPI application was developed for epidemiological studies of this sort). Additionally, uses of data mining from commercial social networking and other sites could be used to gather information relevant to land use, e.g., through sites devoted to the real estate market (e.g., Zillow and Trulia) and to public records. Another opportunity for additional data involves closer collaboration with the private sector. Additional work is needed to develop and test these alternative methods of collecting geocoded information relevant to next generation land-use mapping efforts. Advances in remote sensing data collection and distribution approaches also present important opportunities. The development of nano 
satellites could enhance our potential for continuous monitoring of land surfaces at high spatial resolution and the establishment of systematic land-use observations programs. High-spatial resolution imagery, processed through high-performance computing and aggregated on commercial or open-source platforms can be made available for distributed or crowd-sourced interpretation. The integration of remote sensing-based products with field data, ground-based information, socioeconomic variables and these alternative potential sources of LULC information will open new possibilities to provide and update additional information on land use.

In terms of integration and sharing of data, Theobald (2014) demonstrates the potential value of integrating data of various kinds to create a more complete picture of land use nationally. In order to facilitate such data integration, a data infrastructure would benefit the LULC science community. Emerging examples of such web-based infrastructures include the GeoShare project (https://geoshareproject.org), which is global data compiling data relevant for economic models of agriculture and the GLOBE project (globe.umbc.edu), which has compiled gridded data on a wide range of primary and derived variables relevant to land-use modeling and scenario development. A coordinated interagency, multi-scale effort to develop integrated models and scenarios would certainly benefit from a common platform for data synthesis and integration similar to these efforts.

\section{Establish an open architecture for U.S. LULC scenarios}

Creating national-scale, regionally-differentiated, and spatially-explicit LULC scenarios for the United States will ultimately require those sponsoring the scenario creation process to specify a number of characteristics for the scenarios such as the objectives, key uncertainties that need to be addressed, scenario components (qualitative narratives, quantification, or both), and the information/data outputs, as well as other characteristics such as spatial and temporal scales. The workshop was tasked with exploring these issues during sessions focused on identifying drivers of LULC change, and exploring an approach for using information on drivers to develop a logical structure for LULC scenarios. Both of these objectives were explored in a series of parallel breakout groups, with reflection on the experience during plenary sessions.

During the discussion of drivers, participants were asked to identify what drivers are likely to be important in LULC change in the United States, which effects of land use change are most important to assess, and how feasible it is to examine how sensitive land cover and use are to these drivers, given the data and modeling tools available. Participants did not seek to achieve consensus on these issues but rather explored drivers to provide an overall sense of the issues that are likely to arise in development of the scenarios. Among the highest impact drivers were: human population size and migration; settlement patterns (urban-suburban-rural; compact or sprawling) and housing stock preferences (single family or multi family; size); sources of energy supply (e.g., extent of use of renewable sources such as bioenergy that increase demand for land for cultivation); transportation infrastructure and preferences; agricultural and forestry practices that affect intensity of production; water quality and availability; coastal storms and sea level rise; and policies in any of the above areas that affect technology availability and/or consumer preferences and behavior. But many additional drivers were discussed as well, including international conditions affecting supply and demand of commodity prices; land tenure, prices, and parcellization; changes in disturbance such as invasive species, fire, disease vectors, or 
extreme climate events; and site-level conditions such as soil degradation or watershed conditions.

In reflecting on the process of identifying drivers for scenario development, the overall feeling seemed to be it was a useful exercise to continue refining a list of drivers, focusing on importance, level of uncertainty, and feasibility. Participants cautioned against giving too much significance to the drivers identified during the workshop, although some suggested that the list could be used as a starting point for further discussion. Several points were made about things that will need to be specified at the outset of this stage in scenario generation. Some participants suggested that more careful definition of 'driver' is needed - this can be a tricky question with an issue like LULC, where some things like physical processes may be immediate drivers of land conversion, but underlying policies or factors could prove more important in development of scenarios. A related question was raised about the relationship of different types of drivers as represented in model outputs, and how they are transferred from one research community to another. What's a 'driver' for one community is an 'outcome' for another, and to avoid confusion in scenario development, the relationships need to be specified. Another interesting issue was the relationship of drivers across geographical scales, noting that they differ and interact in complex ways. Whether the new SSPs could be used as international context for U.S. scenarios was discussed. Another issue that will need to be considered is how many drivers you need to investigate and identify - and the need to employ quantitative tools and sensitivity analysis to identify those that are most important as trying to consider too many would be paralyzing. Finally, it was noted that if the scenario process was an inverse one, working from a goal or outcome to explore conditions necessary to achieve it, 'drivers' are not determinants of outcomes but rather need to be defined as conditions or processes you want to influence to get the desired outcome.

In the trial scenario planning exercise, breakout groups were asked to explore how they might group some of the drivers and themes identified into a logical structure that would lead to specification of divergent futures, whether using a narrative or quantitative approach. A focal question was specified for the process: "Considering the next 35 years (i.e., to mid-century), what overarching themes and specific drivers would affect decisions related to land use/management by federal officials, state/local authorities, or others?"

Three of four groups developed an explicit framework. One group adopted a structure that could be seen as similar in some respects to IPCC SRES, but adjusted to be more relevant to U.S. concerns: one dimension focused on consumer preferences and their impact on sustainability - a shift towards more sustainable consumption or preference for current patterns without concern for sustainability; the other focused on the degree of centralization in decision making, with federal decision making dominating in one possible future, and municipal institutions at the other. This group sketched out implications of the four resulting futures for transportation, water, energy, and agriculture. Another group also focused on consumer preferences and impacts on sustainability, but for a second dimension considered resource demand/environmental stress, ranging from high to low environmental impact. This group then sketched out different futures, focusing on factors such as population growth, technology development, energy sources, dietary preferences, and development density. The third framework focused on the importance of environmental policy in society (in a way that somewhat overlapped the sustainability dimension 
of the two other groups) but chose degree and rate of change in technology and improvements in productivity as a second dimension, considering two futures, one of which was dominated by incremental change, and the other which benefitted from breakthroughs.

Reflecting on this portion of the workshop, a number of commenters felt the scenario planning exercise was productive, and a good option for agencies to consider in developing LULC scenarios. Participants commented on the difficulty they had in considering 'black swans' - that there was tendency towards incremental thinking that may need to be overcome. Others raised concern about the path dependency of the futures they identified, and that this was not necessarily a good way to understand what factors would be most important in a country as diverse as the United States over time. This led to a suggestion to involve 'odd ducks' and radical thinkers in the process. The time horizon -35 years - was an important factor that weighed in development of the frameworks: several decided not to focus on climate as much as a result. The prominence of the "transition to sustainability (or not)" as explored in SRES in the work of several groups was seen as either confirming the importance of this factor or illustrating that the SRES scenarios have influenced the way we think about the problem as analysts $-\mathrm{a}$ form of 'availability bias.' Several comments pointed to the danger of 'group think', the importance of trained facilitators, and the need for a careful process with adequate time for groups to look back and change what they have done. Another observation was that how you develop a framework really depends on how it's going to be used - for example, is it something that the scenario 'audience' (e.g., policymakers) will employ to consider what policies would be needed to achieve a certain future, or will the scenarios be used more to precipitate reactions, raise issues that they want to avoid? Being careful in specifying scales for examination was also seen as important one group consciously set out to describe trends occurring at national scale that would provide context for independently-determined trends at regional, state, or municipal scales. But the process may also need to consider how local decisions can aggregate up into outcomes, especially for issues like LULC change. Finally, issues of developing futures in which secondary drivers were consistent and logical: for some of the groups, inconsistent conditions were created (e.g., high population growth with strong environmental concern).

\section{Develop capacity for integrated nested modeling}

Because of the varied scales at which variables influence land-use change, and the multiple scales at which land-use scenarios can be applied, the process of developing land-use scenarios will need to use a nested modeling architecture that links or bridges these multiple scales. Based on existing modeling approaches, model uses, available data resources, and the conceptual models available for describing land-use change, models will need to be employed at three key scales, or scale ranges, elaborated below. A key need in articulating nested model architecture is to identify the appropriate models and data resources available and the specific model components to be developed for each, and the linkages (i.e., scenario and model inputs and outputs) between the levels.

At global to national scales, market dynamics are used to describe demand for land in different sectors based on population and consumption, inter-regional trade and differential levels of productivity and demand by region and sector. It is modeling approaches based on these concepts (like GCAM, Global Trade Analysis Project (GTAP) and EPPA) that provide an 
understanding and estimates of global supply and demand for land-based products that drive the prices of these products and affect land-use decisions in the United States. The workshop participants frequently mentioned the need for this aspect of the modeling framework to be relatively thinly specified within the modeling architecture. The scenarios and models employed at these scales would provide context and a common set of assumptions for more spatially explicit and regionally- and sectorally-specific assessments at lower levels. Data representing the past trends in, and implications of future scenarios about, broad demographic, economic, and policy drivers are required to provide context for future LULC changes.

At national to regional scales, distribution and redistribution of population and economic activity drive demand for land in different sectors. Modeling approaches at this scale might be most useful for identifying changes in the inter-regional distributions of land-use activities and might be best spatially resolved at the county scale, given available data resources. Regional economic and demographic models can provide a platform for understanding differential rates of change, redistributions of population and economic activity, and inclusion of regionally-specific environmental change projections. Temporally-detailed data on regionally-differentiated demographic (e.g., Census) and economic (e.g., USDA Economic Research Service) dynamics, along with the LULC effects of these dynamics (e.g., Censuses of Agriculture and Housing; Forest Inventory and Analysis Program; National Resources Inventory), will support modeling approaches that redistribute demand for various LULC types. Models at these scales are often tailored to the specific sectors of interest in a particular problem area (e.g., forest, agriculture, urban). Their outputs then set the stage for simulation of spatial land allocation mechanism at finer resolutions, which serve to link LULC projections with biophysical processes models for assessment of the environmental and social implications of these changes.

At local to regional scales, concepts from Ricardian economic theory are used to describe how people allocate land-use choices spatially to maximize their returns, based on location factors affecting transportation costs and biophysical factors affecting productivity. By embedding these processes in a nested architecture, amounts of land-use at finer scales can be driven by the broader social and economic forces represented at the coarser scales, but spatially allocated to finer resolutions, and using classification schemes that are best suited to a given question or purpose, based on more geographically resolved predictor variables. They are supported by spatially explicit LULC information, most commonly in the form of the NLCD. A variety of modeling approaches implements these concepts, for example in the CLUE, LTM, SLEUTH, and FORE-SCE models, often including neighborhood variables that account for adjacency effects that alter local returns based on what land uses are nearby. More strongly empirical approaches involve estimation of econometric models based on previous observations of landuse change (Lubowski et al. 2007). Agent-based models also work at these scales, almost exclusively, but could be designed and implemented in ways that provide bridges to other scales. Work is needed in this area to both develop general conceptual models that could be applied anywhere and include all sectors in competition, and develop the data and computing infrastructure for running scenarios with a national scope. 


\section{Options for next steps: program development and sustained effort}

The overall objective of the workshop was to explore options for an interagency process to identify critical uncertainties in projecting changes in land use/land cover, consider data and modeling capabilities, and explore elements of quantitative and qualitative scenarios of landuse/land-cover change that can be used by federal agencies to support multiple needs. A number of gaps to development of such a program and scenarios were identified: lack of comprehensive and coherent data needed to improve research on a number of critical issues, especially the need for consistent, comprehensive, and coordinated land-use observational strategy; the need to address a series of issues that inhibit integration of different types of models needed to link drivers of land-use to land-cover outcomes on a range of spatial scales; and lack of mechanisms that facilitate collaboration across diverse user, research, observation, and modeling communities needed for such an enterprise.

Workshop participants offered several suggestions for moving an interagency scenarios process forward. During the last break-out and plenary discussions, participants were asked to identify both near- and long-term priorities for development of nationally-coordinated LULC scenarios. Both near ( 2 years) and long terms (4-5 years) were assumed to start right away. The following ideas are options for next steps based on a synthesis of the comments made at workshop discussions, and the needs, capabilities/existing resources, and barriers discussed earlier.

\section{Priorities for short-term scenario development}

- Continue exploring options for development of an interagency scenario process and specific elements of quantitative and qualitative scenarios of land-use/land-cover change that can be used by federal agencies. Given the breadth of agency interests, there is an opportunity to continue refining scenario needs in order to provide more detailed specification of desirable characteristics of LULC scenarios, such as the key uncertainties that should be explored, and the spatial and temporal resolution of needed variables. Among topics that require further consideration are the relationship of narrative and quantitative elements, and the extent to which it is useful and possible to nest U.S. scenarios within the globally-oriented scenarios being developed within the parallel RCP scenario process. Specific ideas included:

- Evaluate prior experience: Since LULC data and scenarios were provided as part of the Third NCA, a combination of meetings, a survey, or in-depth interviews of potential users could be an important source of information on regional uses of these LULC products and obtaining input on user views of gaps.

- Convene additional targeted workshops: These should focus on some of the issues identified in the bullet above. There is an opportunity to coordinate with other efforts/workshops (e.g., GEOSHARE).

- Develop a nationally comprehensive inventory of existing LULC resources: This effort could focus in particular on land use, and should include encouragement of shared ontologies (sets of definitions of categories, properties, and interrelationships among different land uses). Such a resource would help to harness existing data more efficiently and provide guidance on the intended use of models, scenarios and related data. The 
common ontologies would go beyond metadata to provide information on how to translate consistently across data sets.

- Develop best practices guidance for county/regional levels on developing/applying landuse/land-cover information: This effort would expand the use of available and new products, encourage use of scenarios in scientifically sound ways, and facilitate development of comparable results. These guidelines should consider application of landuse and land-cover scenarios in the context of other processes, such as demographic and economic change.

- Encourage pilot studies, create test-beds, and provide real world examples for subregional LULC scenarios that are embedded in larger frameworks: It was suggested to focus initially on a few regions of the United States where connections may be easiest because of ongoing application efforts (e.g., California, Maryland and Florida), but to also consider underfunded regions (e.g., Experimental Program to Stimulate Competitive Research or EPSCoR states).

\section{Priorities for long-term scenario development}

- Develop a 'light touch' or flexible national framework for LULC modeling and scenario development: The idea was to develop and make available a linked set of qualitative and quantitative products that describe national trends that are important to future LULC, but to do so in a way that does not prescribe conditions and futures in different regions of the country. The framework would describe the general national context in which regional, state, and local processes would evolve. A nested structure would allow for flexible implementation of qualitative and quantitative inputs and models at multiple scales, depending on the agency or regional requirements of a given application. Specifications of assumptions, category definitions, and process interactions should be only lightly detailed, leaving further specification to a wide range of users. This 'thin' or 'light-touch' approach at the national scale does not preclude developing regional or sectoral scenarios that have strong coupling to the themes or quantification at the national scale.

- Advance efforts to link models (e.g., forestry to urban models, or global continental models to LULC change): Linking models currently poses challenges, namely the computational burden, ontological inconsistencies, and difficulties of assessing uncertainty. One approach for addressing this challenge is to use reduced form or surrogate models that represent relationships among selected variables in more complex and computationally-intensive models in simplified form. However, knowledge and methods for developing surrogates needs to be advanced. Another approach is to provide inputs on factors such as global energy and crop prices, demographic change, and changes in climate that might influence relative levels of productivity on land from scenario narratives or from data sets based on outputs from other models. To address the equilibrium assumption, it should be general practice to generate and examine the range of outcomes produced by any given process (and, by extension, model) of land-use change under different scenarios.

- Conduct research to improve representation of multi-scale processes that account for teleconnections and complex networks that could affect both land-cover and land-use dynamics: This will enhance capacity to understand and project land cover, and direct and indirect effects between sectors.

- Connect scenario user and developer groups: This idea included two options: 
○ A suggestion was made to engage regional organizations including stakeholders working with federal activities such as RISA programs and the Climate Science Centers in workshops, interviews, and/or surveys.

- Another suggestion was to help establish and incentivize a scenarios research community that involves senior/junior researchers and students, and foster relationships with climate community users.

- Develop and implement a protocol for mapping land use in a nationally consistent manner at comparable spatial and temporal resolutions to NLCD (i.e., $30 \mathrm{~m}$ every five years): This would begin with agreement on a common land-use classification scheme and implementation through integration of multiple existing remotely sensed, census, and survey datasets, and move towards identification of new data collection efforts that would improve national-scale land-use monitoring. .

Finally, two additional overarching ideas concern how to make future efforts and interactions most productive:

- Consider development of national scenarios (and supporting research) an on-going process: Several comments indicated that development of LULC scenarios should not be a one-off process, especially when considering the needs of the sustained assessment process envisioned by the NCA. Ongoing commitment will be required to build a capacity for replicable observations and modeling that support use of the information created in scenarios and other interpretive products. These long-term efforts need to focus on the challenges to model integration, as well as capacity to link activities in a nested framework that bridges spatial scales and facilitates understanding of cross-sectoral interactions. To facilitate sustained interactions, better understanding in the research community on needs, good practice by users, and long-term interactions will be required, possibly in periodic conferences. Such conferences could be oriented towards improving connections among different research communities, like the Energy Modeling Forum 'Snowmass' workshops, and linking producer and user communities for the sustained assessment.

- Encourage methodological pluralism and innovation: Agencies could jointly or individually commission or sponsor competitions to create individual scenario products. There was also a suggestion to prepare a community white paper to gather broad input to reflect on next steps in a more broad-based fashion. It was observed that it was important not to underestimate the magnitude of the task of developing the integrated capacity for observations, research, and modeling needed to develop LULC data and scenarios for scientific research and applications. Given that the human-environmental systems involved are every bit as complex as those involved in the climate system, the research support and community-building activities need to be planned at the scale of those associated with CMIP. 


\section{References}

Bierwagen, B. G., D. M. Theobald, C. R. Pyke, A. Choate, P. Groth, J. V. Thomas, and P. Morefield. (2010). National housing and impervious surface scenarios for integrated climate impact assessments. Proceedings of the National Academy of Sciences, 107(49), 20887-20892.

Buizer, J. L., P. Fleming, S. L. Hays, K. Dow, C. B. Field, D. Gustafson, A. Luers, and R. H. Moss, Report on Preparing the Nation for Change: Building a Sustained National Climate Assessment Process, National Climate Assessment and Development Advisory Committee, 2013.

Calvin, K., M. Wise, L. Clarke, J. Edmonds, P. Kyle, P. Luckow, and A. Thomson. 2013. Implications of simultaneously mitigating and adapting to climate change: initial experiments using GCAM. Climatic Change, 117(3), 545-560.

Carpenter, S., P. Pingali, E. Bennett, and M. Zurek, Eds. 2005: Ecosystems and Human Wellbeing: Volume 2: Scenarios. Findings of the Scenarios Working Group of the Millennium Ecosystem Assessment. Island Press, Washington, District of Columbia, 560 pp.

Carter, T. R., R. N. Jones, X. Lu, S. Bhadwal, C. Conde, L. O. Mearns, B. C. O’Neill, M. D. A. Rounsevell and M. B. Zurek, 2007: New Assessment Methods and the Characterisation of Future Conditions. Climate Change 2007: Impacts, Adaptation and Vulnerability. Contribution of Working Group II to the Fourth Assessment Report of the Intergovernmental Panel on Climate Change, M. L. Parry, O. F. Canziani, J. P. Palutikof, P. J. van der Linden and C. E. Hanson, Eds., Cambridge University Press, Cambridge, UK, 133-171.

Clarke, K.C., and L. J. Gaydos. 1998. Loose-coupling a cellular automaton model and GIS: longterm urban growth prediction for San Francisco and Washington/Baltimore. International Journal of Geographical Information Science, 12(7), 699-714.

Davies-Barnard, T., Valdes, P. J., Singarayer, J. S., and Jones, C. D. 2014. Climatic impacts of land-use change due to crop yield increases and a universal carbon tax from a scenario model, J. Clim., 27, 1413-1424, 10.1175/jcli-d-13-00154.1.

DOE (U.S. Department of Energy). 2013. Developing a Framework for Regional Integrated Assessment Modeling. Available at http://climatemodeling.science.energy.gov/sites/default/files/RIAM.pdf.

Gong, P., Wang, J., Yu, L., Zhao, Y.C., Zhao, Y.Y., Liang, L., Niu, Z.G., Huang, X.M., Fu, H.H., Liu, S., Li, C.C., Li, X.Y., Fu, W., Liu, C.X., Xu, Y., Wang, X.Y., Cheng, Q., Hu, L.Y., Yao, W.B., Zhang, H., Zhu, P., Zhao, Z.Y., Zhang, H.Y., Zheng, Y.M., Ji, L.Y., Zhang, Y.W., Chen, H., Yan, A., Guo, J.H., Yu, L., Wang, L., Liu, X.J., Shi, T.T., Zhu, M.H., Chen, Y.L., Yang, G.W., Tang, P., Xu, B., Ciri, C., Clinton, N., Zhu, Z.L., Chen, J., Chen, J. 2013. Finer resolution observation and monitoring of global land cover: first mapping results with Landsat TM and ETM+ data, International Journal of Remote Sensing 34(7): pp.2607-2654.

Hansen, M. C., P. V. Potapov, R. Moore, M. Hancher, S. A. Turubanova, A. Tyukavina, D. Thau, S. V. Stehman, S. J. Goetz, T. R. Loveland, A. Kommareddy, A. Egorov, L. Chini, C. O. Justice, and J. Townshend, R. G., J. R. G. 2013. High-resolution global maps of 21st-century forest cover change. Science, 342(6160), 850-853.

DOI:10.1126/science.1244693. 
Irwin, E. G., and J. Geoghegan. 2001. Theory, data, methods: developing spatially explicit economic models of land use change. Agriculture, Ecosystems \& Environment, 85(1), 7 24.

Jones, A. D., Collins, W. D., Edmonds, J., Torn, M. S., Janetos, A., Calvin, K. V., Thomson, A., Chini, L. P., Mao, J., Shi, X., Thornton, P., Hurtt, G. C., and Wise, M. 2013. Greenhouse gas policy influences climate via direct effects of land-use change. J. Clim., 26, 36573670, 10.1175/jcli-d-12-00377.1.

Lawler, J. J., D. J. Lewis, E. Nelson, A. J. Plantinga, S. Polasky, J. C. Withey, D. P. Helmers, S. Martinuzzi, D. Pennington, and V. C. Radeloff. 2014. Projected land-use change impacts on ecosystem services in the United States. Proceedings of the National Academy of Sciences, 111(20), 7492-7497.

Ligmann-Zielinska, A., and P. Jankowski. 2010. Exploring normative scenarios of land use development decisions with an agent-based simulation laboratory. Computers, Environment and Urban Systems, 34(5), 409-423.

Lubowski, R. N., A. J. Plantinga, and R. N. Stavins. 2008. What drives land-use change in the United States? A national analysis of landowner decisions. Land Economics, 84(4), 529550.

Lubowski, R. N., A. Plantinga, and R. N. Stavins. 2007. What Drives Land-use Changes in the United States?: A National Analysis of Landowner Decisions. (No. 13572). National Bureau of Economic Research.

Magliocca, N. R., D. G. Brown, and E. C. Ellis. 2013. Interactions between market-driven livelihood transitions and induced agricultural intensification. PLoS One 8(9): e73241.

Morgan, M. G., and D. W. Keith. 2008. Improving the way we think about projecting future energy use and emissions of carbon dioxide. Climatic Change, 90(3), 189-215. DOI: 10.1007/s10584-008-9458-1.

Moss, R. H., J. A. Edmonds, K. Hibbard, M. Manning, S. K. Rose, D. Van Vuuren, T. R. Carter, S. Emori, M. Kainuma, T. Kram, G. A. Meehl, J. F. B. Mitchell, N. Nakicenovic, K. Riahi, S. J. Smith, R. J. Stouffer, A. M. Thomson, J. P. Weyant, and T. J. Wilbanks. 2010. The next generation of scenarios for climate change research and assessment. Nature 463:747-756.

Nakicenovic, N. and R. Swart, editors. 2000. Special Report on Emissions Scenarios. Intergovernmental Panel on Climate Change (IPCC). Cambridge University Press, Cambridge, 570 pp.

NRC (National Research Council). 2013. Advancing Land Change Modeling: Opportunities and Research Requirements. Washington, DC: National Academies Press.

Parker, D. C., S. M. Manson, M. A. Janssen, M. J. Hoffmann, and P. Deadman . 2003. Multiagent systems for the simulation of land-use and land-cover change: A review. Annals of the Association of American Geographers, 93(2): 314-337.

Parson, E. A., V. Burkett, K. Fisher-Vanden, D. Keith, L. O. Mearns, H. Pitcher, C. Rosenzweig, and M. Webster. 2007. Global Change Scenarios: Their Development and Use. Climate Change Science Program, Washington, D.C.

Pijanowski, B. C., D. G. Brown, B. A. Shellito, and G. A. Manik. 2002. Using neural nets and GIS to forecast land use changes: a land transformation model. Computers, Environment and Urban Systems, 26(6): 553-575. 
Pontius, G. R., and J. Malanson. (2005). Comparison of the structure and accuracy of two land change models. International Journal of Geographical Information Science, 19(2), 243265.

Reilly, J., J. Melillo, Y. Cai, D. Kicklighter, A. Gurgel, S. Paltsev, T. Cronin, A. Sokolov, and A. Schlosser. 2012. Using land to mitigate climate change: hitting the target, recognizing the trade-offs. Environmental Science \& Technology, 46(11), 5672-5679.

Robinson, D.T., and D.G. Brown. 2009. Evaluating the effects of land-use development policies on ex-urban forest cover: An integrated agent-based GIS approach. International Journal of Geographical Information Science, 23(9), 1211-1232.

Rounsevell, M. D. A., A. Arneth, P. Alexander, D. G. Brown, N. de Noblet-Ducoudré, E. Ellis, J. Finnigan, K. Galvin, N. Grigg, I. Harman, J. Lennox, N. Magliocca, D. Parker, B. C. O'Neill, P. H. Verburg, and O. Young. 2014. Towards decision-basedd global land use models for improved understanding of the Earth system. Earth System Dynamics Discussions, 5: 117-137.

Sengupta, R., C. Lant, S. Kraft, J. Beaulieu, W. Peterson, and T. Loftus. 2005. Modeling enrollment in the Conservation Reserve Program by using agents within spatial decision support systems: an example from southern Illinois.Environment and Planning B, 32(6), 821.

Sexton, J. O., Song, X.-P., Feng, M., Noojipady, P., Anand, A., Huang, C., Kim, D.-H., Collins, K.M., Channan, S., DiMiceli, C., Townshend, J.R.G. (2013). Global, 30-m resolution continuous fields of tree cover: Landsat-based rescaling of MODIS Vegetation Continuous Fields with lidar-based estimates of error. International Journal of Digital Earth, 130321031236007. DOI:10.1080/17538947.2013.786146.

Soares-Filho, B. S., D. C. Nepstad, L. M. Curran, G. G. Cerqueira, R. A. Garcia, C. A. Ramos, E. Voll, A. McDonald, P. Lefebvre, and P. Schlesinger. 2006. Modelling conservation in the Amazon basin. Nature 440: 520-523.

Sohl, T. L., K. L. Sayler, M. A. Drummond, and T. R. Loveland. 2007. The FORE-SCE model: a practical approach for projecting land cover change using scenario-based modeling. Journal of Land Use Science, 2(2), 103-126.

Theobald, D. M. (2014). Development and Applications of a Comprehensive Land Use Classification and Map for the US. PloS one, 9(4), e94628.

U.S. EPA. Land-Use Scenarios: National-Scale Housing-Density Scenarios Consistent with Climate Change Storylines (Final Report). EPA/600/R-08/076F, 2009.

Verburg, P. H., W. Soepboer, A. Veldkamp, R. Limpiada, V. Espaldon, and S. S. Mastura. 2002. Modeling the spatial dynamics of regional land use: the CLUE-S model. Environmental management, 30(3), 391-405.

Wear, D. N. 2010. Forecasts of County-Level Land Uses Under Three Future Scenarios for the 2010 RPA Assessment. U.S. Forest Service Gen. Tech. Report.

West, T.O., Y. Le Page, M. Huang, J. Wolf, and A.M. Thomson. 2014. "Downscaling global land cover projections from an integrated assessment model for use in regional analyses: results and evaluation for the US from 2005 to 2095." Environmental Research Letters 9(6):064004. DOI: 10.1088/1748-9326/9/6/064004.

Zurek, M. B. and T. Henrichs. 2007. Linking scenarios across geographical scales in international environmental assessments. Technological Forecasting and Social Change 74(8): 1282-1295. 


\title{
Appendices
}

\section{Appendix A: Workshop Agenda}

\author{
Workshop on U.S. Land Use/Land Cover Scenarios and Projections \\ June 25-27, 2014 \\ Hilton Washington DC/Rockville Hotel \& Executive Meeting Center \\ 1750 Rockville Pike, Rockville, MD 20852 \\ (Room: Plaza II)
}

\author{
June 25: Wednesday \\ 0900 - 1030 Welcome \& Overview: Session Chair: Dan Brown, University of Michigan \\ 0900-0910 Welcome and U.S. Global Change Research Program (USGCRP) perspective (Allison Leidner, \\ NASA) \\ 0910-0930 Overview of existing scenario efforts (Richard Moss, Joint Global Change Research Institute - \\ Pacific Northwest National Laboratory) \\ 0930-0955 Overview of workshop (Dan Brown, University of Michigan) \\ 0955-1015 Outcomes of companion workshop on scenarios of U.S. demographic change (Bhudu Bhaduri, \\ Oak Ridge National Laboratory) \\ 1015-1035 Use of scenarios in decision making (Chris Weaver, USGCRP) \\ 1035-1050 BREAK (light refreshments at the Plaza Foyer) \\ 1050 - 1300 Defining User Needs: Session Chair: Dan Brown, University of Michigan \\ 1050-1200 User Needs Panel (10 minutes each) \\ John Hall, Department of Defense \\ Matt Nicholson, Environmental Protection Agency \\ Linda Langner, USDA Forest Service \\ Scott Malcolm, USDA Economic Research Service \\ Fred Lipschultz, National Climate Assessment, USGCRP \\ Ben Rasmussen, Department of Transportation \\ 1200-1300 Group Discussion of User Needs \\ 1300-1400 LUNCH (at the Plaza Foyer) \\ 1400 - 1730 Drivers of LULC Change: Session Chair: Marc Levy, Columbia University (CIESIN) \\ 1400-1415 Perspectives on land use drivers (Ruben Lubowksi, Environmental Defense Fund) \\ 1415-1430 Perspectives on land cover drivers (Terry Sohl, USGS) \\ 1430-1445 Charge to Breakout Groups
}


Key questions:

1) What will drive land use in the future?

2) What effects of land use change are most important to assess?

1445-1615 Breakout Groups

- Group 1 (Plaza II Room)

- Group 2 (Wilson Room)

- Group 3 (Truman Room)

- Group 4 (Monroe Room)

1615-1630 BREAK (light refreshments at the Plaza Foyer)

1630-1730 Plenary: Report outs and group discussion

(10 minutes per group and 20 minutes open discussion)

June 26: Thursday

0900-1200

0900-0915

0915-0930

0930-0945

0945-1130

$1130-1145$

$1145-1245$

1245-1730:

$1245-1300$

$1300-1400$

$1400-1415$

$1415-1430$

$1430-1615$
Scenario Design: Session Chair Richard Moss, Joint Global Change Research Institute

Defining storylines and scenarios for forest resource assessments (Dave Wear, USDA FS)

Developing scenario storylines for representative agricultural pathways (RAPs) (Joshua Elliott, Agricultural Model Intercomparison and Improvement Project - AgMIP)

Charge to Breakout Groups

Key questions:

1) What's needed to construct scenarios at multiple scales?

2) What might LULCC scenarios and narratives look like?

Breakout Groups

- $\quad$ Group 1 in Plaza II Room

- Group 2 in Wilson Room

- Group 3 in Truman Room

- Group 4 in Monroe Room

BREAK (light refreshments at the Plaza Foyer)

Plenary: Report outs and group discussion

Scenario Needs: Session Chair: Allison Leidner, NASA

Existing data sources for scenario construction (Fernando Sedano, University of Maryland)

LUNCH (at the Plaza Foyer)

Implementing shared socioeconomic pathways (SSPs) (Kate Calvin, JGCRI)

Charge to break out groups:

Key questions:

1) What are existing resources (data, models, analysis) for constructing scenarios?

2) What new products (data, software, models and analyses) are needed for scenarios?

Breakout Groups

- Group 1 in Plaza II Room 
- Group 2 in Wilson Room

- Group 3 in Truman Room

- $\quad$ Group 4 in Monroe Room

1615-1630 BREAK (light refreshments at the Plaza Foyer)

1630-1730 Plenary: Report outs and group discussion

\section{June 27: Friday}

0900-1200 Defining Next Steps: Session Chair Allison Thomson, Joint Global Change Research Institute

0900-0915 Charge to Break-out groups

Key questions:

1) Any new thoughts/input to consider in scenario planning?

2) What is needed to move forward in constructing LULCC scenarios?

3) What aspects of next steps are needed to support sustained assessment?

0915-1045 Breakout Groups

- $\quad$ Group 1 in Plaza II Room

- Group 2 in Wilson Room

- Group 3 in Truman Room

- Group 4 in Monroe Room

1045-1100 BREAK (light refreshments at the Plaza Foyer)

1100-1200 Plenary: Report outs and group discussion

1200-1300: Synthesis of meeting and recommendations and discussion of next steps

1200-1245 Recap of Key Recommendations, review suggested path forward, and discussion (Dan Brown, University of Michigan) (15 minute talk and discussion)

1245-1300 Concluding remarks (Richard Moss, JGCRI; Linda Langner, USDA FS) 


\section{Appendix B: Workshop Participants List}

\begin{tabular}{|c|c|c|c|}
\hline$\#$ & Last Name & First Name & Affiliation \\
\hline 1 & Aragon-Long & Susan & U.S. Global Change Research Program \\
\hline 2 & Beach & Robert & RTI International \\
\hline 3 & Bhaduri & Budhendra L. & Oak Ridge National Laboratory \\
\hline 4 & Bierwagen & Britta & U.S. Environmental Protection Agency \\
\hline 5 & Bright & Eddie & Oak Ridge National Laboratory \\
\hline 6 & Brown & Dan & University of Michigan \\
\hline 7 & Brunelle & Brigitte & U.S. Department of Defense \\
\hline 8 & Calvin & Kate & Joint Global Change Research Institute, PNNL \\
\hline 9 & Carter & Tess & U.S. Global Change Research Program \\
\hline 10 & Cavallaro & Nancy & U.S. Department of Agriculture \\
\hline 11 & Claggett & Peter & U.S. Geological Survey \\
\hline 12 & Cole & Jefferson & U.S. Environmental Protection Agency \\
\hline 13 & Costanza & Jennifer & NC State University \\
\hline 14 & Coulston & John & USDA Forest Service \\
\hline 15 & Delgado & Alison & USGCRP / JGCRI \\
\hline 16 & Easterling & David & NOAA/National Climatic Data Center \\
\hline 17 & Eitler & Cyrena & Department of Defense \\
\hline 18 & Feddema & Johan & University of Kansas \\
\hline 19 & Fischhoff & Ilya & U.S. Global Change Research Program \\
\hline 20 & Gamas & Julia & U. S. Environmental Protection Agency \\
\hline 21 & Geernaert & Gary & U.S. Department of Energy \\
\hline 22 & Golden-Chen & Bryce & U.S. Global Change Research Program \\
\hline 23 & Grambsch & Anne & U.S. Environmental Protection Agency \\
\hline 24 & Gutman & Garik & NASA HQ \\
\hline 25 & Hall & John & U.S. Department of Defense \\
\hline 26 & Hansen & Matthew & University of Maryland \\
\hline 27 & Hellwinckel & Chad & University of Tennessee \\
\hline 28 & Hurtt & George & U.S. Department of Energy \\
\hline 29 & Irwin & Elena & Ohio State University \\
\hline 30 & Janetos & Tony & Boston University \\
\hline 31 & Jones & Andrew & Lawrence Berkeley National Laboratory \\
\hline 32 & Kuperberg & Michael & U.S. Department of Energy \\
\hline 33 & Landis & John & University of Pennsylvania \\
\hline 34 & Langner & Linda & USDA Forest Service \\
\hline 35 & Leidner & Allison & NASA Earth Science Division/USRA \\
\hline 36 & Levy & Marc & CIESIN \\
\hline 37 & Lipschultz & Fred & U.S. Global Change Research Program \\
\hline 38 & Loveland & Thomas & U.S. Geological Survey \\
\hline 39 & Lubowski & Ruben & Environmental Defense Fund \\
\hline 40 & Magliocca & Nicholas & SESYNC \\
\hline 41 & Malcolm & Scott & U.S. Department of Agriculture - ERS \\
\hline 42 & Mockrin & Miranda & USDA Forest Service \\
\hline 43 & Monier & Erwan & MIT \\
\hline 44 & Morefield & Phil & U. S. Environmental Protection Agency \\
\hline 45 & Moss & Richard & Joint Global Change Research Institute, PNNL \\
\hline 46 & Mueller & Rick & U.S. Department of Agriculture / NASS \\
\hline 47 & Nelson & Gerald & UIUC \\
\hline 48 & Nicholson & Matt & U. S. Environmental Protection Agency \\
\hline
\end{tabular}




\begin{tabular}{|l|l|l|l|}
\hline $\mathbf{4 9}$ & Obersteiner & Michael & IIASA \\
\hline $\mathbf{5 0}$ & Pijanowski & Bryan & Purdue University \\
\hline $\mathbf{5 1}$ & Reed & Brad & U.S. Geological Survey \\
\hline $\mathbf{5 2}$ & Sands & Ron & U.S. Department of Agriculture - ERS \\
\hline $\mathbf{5 3}$ & Schmerfeld & John & U.S. Fish and Wildlife Service \\
\hline $\mathbf{5 4}$ & Sedano & Fernando & University of Maryland \\
\hline $\mathbf{5 5}$ & Shevliakova & Elena & Princeton University \\
\hline $\mathbf{5 6}$ & Shrestha & Gyami & U.S. Global Change Research Program \\
\hline $\mathbf{5 7}$ & Sleeter & Ben & U.S. Geological Survey \\
\hline $\mathbf{5 8}$ & Sohl & Terry & U.S. Geological Survey EROS \\
\hline $\mathbf{5 9}$ & Sohngen & Brent & Ohio State University \\
\hline $\mathbf{6 0}$ & Theobald & Dave & Conservation Science Partners \\
\hline $\mathbf{6 1}$ & Thomson & Allison & Joint Global Change Research Institute, PNNL \\
\hline $\mathbf{6 2}$ & Trtanj & Juli & NASA \\
\hline $\mathbf{6 3}$ & Vallario & Robert & U.S. Department of Energy - IARP \\
\hline $\mathbf{6 4}$ & Wear & David & USDA Forest Service \\
\hline $\mathbf{6 5}$ & Weaver & Chris & OSTP/USGCRP \\
\hline $\mathbf{6 6}$ & West & Tris & Joint Global Change Research Institute, PNNL \\
\hline $\mathbf{6 7}$ & Westervelt & Jim & Army Corps - ERDC \\
\hline $\mathbf{6 8}$ & Wickham & Jim & U.S. Environmental Protection Agency \\
\hline
\end{tabular}




\title{
Appendix C: Workshop Science Steering Committee and Federal Coordinating Group Members
}

\author{
Science Steering Committee
}

Dan Brown, University of Michigan (co-chair)

Richard Moss, Joint Global Change Research Institute (co-chair)

Budhendra Bhaduri, Oak Ridge National Laboratory

Chris Justice, University of Maryland

Marc Levy, Columbia University

Ruben Lubowski, Environmental Defense Fund

Ben Sleeter, U.S. Department of the Interior Geological Survey

Allison Thomson, Joint Global Change Research Institute

Dave Wear, U.S. Department of Agriculture Forest Service

\section{Federal Coordinating Group}

Linda Langner, U.S. Department of Agriculture Forest Service (co-lead)

Allison Leidner, National Aeronautics and Space Administration (co-lead)

Britta Bierwagen, U.S. Environmental Protection Agency

Dave Easterling, National Oceanic and Atmospheric Administration

John Hall, U.S. Department of Defense

Brad Reed, U.S. Department of the Interior Geological Survey

\section{U.S. Global Change Research Program Scenarios and Interpretive Science Coordinating Group}

Linda Langner, U.S. Department of Agriculture Forest Service (co-chair)

Bob Vallario, U.S. Department of Energy (co-chair)

Susan Aragon-Long, U.S. Global Change Research Program

Virginia Burkett, U.S. Department of the Interior Geological Survey

Alison Delgado, U.S. Global Change Research Program/Joint Global Change Research Institute

Dave Easterling, National Oceanic and Atmospheric Administration

Anne Grambsch, U.S. Environmental Protection Agency

John Hall, U.S. Department of Defense

Allison Leidner, National Aeronautics and Space Administration

Fred Lipschultz, U.S. Global Change Research Program

Chris Weaver, U.S. Global Change Research Program 


\section{Appendix D: List of Global Land Cover/Land Use Products}

\begin{tabular}{|c|c|c|c|c|c|c|c|c|c|c|}
\hline ID & Name & $\begin{array}{c}\text { Data } \\
\text { acquisition }\end{array}$ & Release & Updates & $\begin{array}{l}\text { Spatial } \\
\text { resolution }\end{array}$ & Source & $\begin{array}{l}\text { Data } \\
\text { type }\end{array}$ & Subject matter & $\begin{array}{l}\text { Variable } \\
\text { type }\end{array}$ & Developed \\
\hline 1 & $\begin{array}{l}\text { IGBP Land Cover } \\
\text { Classification }\end{array}$ & $1992-1993$ & 1997 & 1999 & $1 \mathrm{~km}$ & RS/AHVRR & Raster & LCLU & Disc. & USGS,UNL,JRC-EC \\
\hline 1.1 & Global Ecosystems & $1992-1994$ & 1997 & & $1 \mathrm{~km}$ & RS/AHVRR & Raster & Ecosystem & Disc. & USGS,UNL,JRC-EC \\
\hline 1.2 & $\begin{array}{l}\text { USGS Land Use/Land } \\
\text { Cover System }\end{array}$ & 1992-1994 & 1997 & & $1 \mathrm{~km}$ & RS/AHVRR & Raster & LCLU & Disc. & USGS,UNL,JRC-EC \\
\hline 1.3 & $\begin{array}{l}\text { Simple Biosphere } \\
\text { Model }\end{array}$ & 1992-1994 & 1997 & & $1 \mathrm{~km}$ & RS/AHVRR & Raster & GCM & Disc. & USGS,UNL,JRC-EC \\
\hline 1.4 & $\begin{array}{l}\text { Simple Biosphere } \\
\text { Model } 2\end{array}$ & 1992-1994 & 1997 & & $1 \mathrm{~km}$ & RS/AHVRR & Raster & GCM & Disc. & USGS,UNL,JRC-EC \\
\hline 1.5 & $\begin{array}{l}\text { Biosphere Atmosphere } \\
\text { Transfer Scheme }\end{array}$ & 1992-1994 & 1997 & & $1 \mathrm{~km}$ & RS/AHVRR & Raster & Atmosphere & Disc. & USGS,UNL,JRC-EC \\
\hline 1.6 & Vegetation Life forms & $1992-1994$ & 1997 & & $1 \mathrm{~km}$ & RS/AHVRR & Raster & Vegetation & Disc. & USGS,UNL,JRC-EC \\
\hline 2 & $\begin{array}{c}\text { Global Land Cover } \\
2000\end{array}$ & $1999-2000$ & 2002 & & $1 \mathrm{~km}$ & $\begin{array}{l}\text { RS/SPOT- } \\
\text { Vegetation }\end{array}$ & Raster & LCLU & Disc. & JRC-EC \\
\hline 3 & Globcover & $2005-2006$ & 2006 & 2009 & $300 \mathrm{~m}$ & RS/MERIS & Raster & LCLU & Disc. & $\begin{array}{l}\text { JRC, EEA, FAO, UNEP, } \\
\text { GOFC-GOLD and IGBP }\end{array}$ \\
\hline 4 & $\begin{array}{l}\text { UMD Global Land } \\
\text { Cover Classification }\end{array}$ & 1981-1994 & 1998 & & $8 \mathrm{~km} / 1 \mathrm{~km}$ & RS/AHVRR & Raster & LCLU & Disc. & University of Maryland \\
\hline 4.1 & $\begin{array}{l}\text { MCD12C1 (Land } \\
\text { cover) }\end{array}$ & $2000-2014$ & Annual & & $5600 \mathrm{~m}$ & RS/MODIS & Raster & LCLU & Disc. & University of Maryland \\
\hline 4.2 & $\begin{array}{l}\text { MCD12Q1 (Land } \\
\text { cover) }\end{array}$ & $2000-2014$ & Annual & & $500 \mathrm{~m}$ & RS/MODIS & Raster & LCLU & Disc. & University of Maryland \\
\hline 4.3 & $\begin{array}{l}\text { MCD12Q2 (Land } \\
\text { Cover Dynamics) }\end{array}$ & $2001-2006$ & Annual & & $500 \mathrm{~m}$ & RS/MODIS & Raster & LCLU & Disc. & University of Maryland \\
\hline 4.4 & $\begin{array}{l}\text { MOD44A (Vegetation } \\
\text { Cover Conversion) }\end{array}$ & $2000-2014$ & Quarterly & & $250 \mathrm{~m}$ & RS/MODIS & Raster & LCLU & Disc. & University of Maryland \\
\hline 4.5 & $\begin{array}{l}\text { MOD44B (Vegetation } \\
\text { Cont. Fields) }\end{array}$ & $2000-2014$ & Annual & & $250 \mathrm{~m}$ & RS/MODIS & Raster & Vegetation & Cont. & University of Maryland \\
\hline 5 & $\begin{array}{l}\text { Contemporary global } \\
\text { cropland and grassland }\end{array}$ & $1999-2000$ & 2002 & & 5 minutes & $\begin{array}{l}\text { RS/FAO } \\
\text { Stats }\end{array}$ & RASTER & Cropland/Grassland & Disc. & $\begin{array}{l}\text { Netherlands Environmental } \\
\text { Assessment Agency }\end{array}$ \\
\hline 6 & $\begin{array}{l}\text { FAO/UNESCO Soil } \\
\text { Map of the World }\end{array}$ & 1961 & 1974 & & $1: 5000000$ & $\begin{array}{l}\text { Surveys/Map } \\
\text { compilation }\end{array}$ & Vector & Soil & Disc. & FAO/UNESCO \\
\hline 7 & $\begin{array}{l}\text { Harmonized World } \\
\text { Soil Database v } 1.2\end{array}$ & 2008 & 2012 & & $1 \mathrm{~km}$ & $\begin{array}{l}\text { Surveys/Map } \\
\text { compilation }\end{array}$ & Raster & Soil & Disc. & $\begin{array}{l}\text { FAO with IIASA, ISRIC- } \\
\text { World Soil Information, } \\
\text { Institute of Soil Science, } \\
\text { Chinese Academy of } \\
\text { Sciences (ISSCAS), and the }\end{array}$ \\
\hline
\end{tabular}




\begin{tabular}{|c|c|c|c|c|c|c|c|c|c|}
\hline & & & & & & & & & $\begin{array}{l}\text { Joint Research Centre of the } \\
\text { European Commission (JRC) }\end{array}$ \\
\hline 8 & $\begin{array}{l}\text { Global Terrain Slope } \\
\text { and Aspect Data }\end{array}$ & 2006 & & & & & & & \\
\hline 8.1 & USGS HydroSHEDS & 2000 & 2006 & $90 \mathrm{~m}$ & RS/SRTM & Raster & $\begin{array}{l}\text { Elevation, aspect, } \\
\text { slope }\end{array}$ & & USGS \\
\hline 8.2 & CGIAR-CSI & 2000 & 2008 & $90 \mathrm{~m}$ & RS/SRTM & Raster & $\begin{array}{l}\text { Elevation, aspect, } \\
\text { slope }\end{array}$ & & CGIAR-CSI \\
\hline 8.3 & LP DAAC-SRTM Plus & 2000 & 2012 & $90 \mathrm{~m}$ & RS/SRTM & Raster & $\begin{array}{l}\text { Elevation, aspect, } \\
\text { slope }\end{array}$ & & USGS \\
\hline 9 & $\begin{array}{l}\text { Historical changes in } \\
\text { croplands }\end{array}$ & $\begin{array}{c}1700 \text { to } \\
1992\end{array}$ & 1999 & 5 minutes & Maps & Raster & Cropland & Cont. & \\
\hline 10 & $\begin{array}{c}\text { History Database of } \\
\text { the Global } \\
\text { Environment (HYDE) }\end{array}$ & $1700-2000$ & & $\begin{array}{c}0.5 \\
\text { degrees }\end{array}$ & & 50 years & $\begin{array}{l}\text { Cropland; } \\
\text { grassland }\end{array}$ & Disc. & $\begin{array}{l}\text { Netherlands Environmental } \\
\text { Assessment Agency }\end{array}$ \\
\hline 11 & $\begin{array}{c}\text { History Database of } \\
\text { the Global } \\
\text { Environment (HYDE } \\
3.1 \text { ) }\end{array}$ & $\begin{array}{l}10,000 \mathrm{bc} \\
\text { to } \mathrm{ad} 2000\end{array}$ & & 5 minutes & & $\begin{array}{c}100 \\
\text { years }\end{array}$ & $\begin{array}{l}\text { Cropland; } \\
\text { grassland }\end{array}$ & Disc. & $\begin{array}{l}\text { Netherlands Environmental } \\
\text { Assessment Agency }\end{array}$ \\
\hline 12 & $\begin{array}{l}\text { Landsat Vegetation } \\
\text { Cont. Fields }\end{array}$ & $\begin{array}{l}\text { Two epochs } \\
(2000 ; 2005)\end{array}$ & 2013 & $30 \mathrm{~m}$ & RS/Landsat & Raster & Vegetation & Cont. & University of Maryland \\
\hline 13 & Global Forest Change & $2000-2012$ & 2013 & $30 \mathrm{~m}$ & RS/Landsat & Raster & Forest cover & Disc. & University of Maryland \\
\hline 14 & $\begin{array}{c}\text { Finer Resolution } \\
\text { Observation and } \\
\text { Monitoring of Global } \\
\text { Land Cover (FROM- } \\
\text { GLC) }\end{array}$ & 1984-2011 & 2012 & $30 \mathrm{~m}$ & RS/Landsat & Raster & LCLU & Disc. & Tsinghua University \\
\hline
\end{tabular}




\section{Appendix E: List of National Land Cover/Land Use Products}

\begin{tabular}{|c|c|c|c|c|c|c|c|c|c|c|}
\hline ID & Name & $\begin{array}{c}\text { Data } \\
\text { acquisition }\end{array}$ & Release & Updates & $\begin{array}{c}\text { Spatial } \\
\text { resolution }\end{array}$ & Source & Data type & Subject matter & $\begin{array}{c}\text { Variable } \\
\text { type }\end{array}$ & Developed \\
\hline 15 & LANDFIRE & & & & & & & & & \\
\hline 15.1 & $\begin{array}{l}\text { Existing Vegetation } \\
\text { Cover }\end{array}$ & 2001 & 2009 & Biannual & $30 \mathrm{~m}$ & RS/Landsat & Raster & Vegetation & Disc. & $\begin{array}{l}\text { USGS, DOI, Nature } \\
\text { Conservancy, Wildland } \\
\text { Fire Mngt. }\end{array}$ \\
\hline 15.2 & $\begin{array}{c}\text { Existing Vegetation } \\
\text { Type }\end{array}$ & 2001 & 2009 & Biannual & $30 \mathrm{~m}$ & RS/Landsat & Raster & Vegetation & Disc. & $\begin{array}{l}\text { USGS, DOI, Nature } \\
\text { Conservancy, Wildland } \\
\text { Fire Mngt. }\end{array}$ \\
\hline 15.3 & $\begin{array}{l}\text { Fire Behavior Fuel } \\
\text { Models }\end{array}$ & 2001 & 2009 & Biannual & $30 \mathrm{~m}$ & RS/Landsat & Raster & Fire & Disc. & $\begin{array}{l}\text { USGS, DOI, Nature } \\
\text { Conservancy, Wildland } \\
\text { Fire Mngt. }\end{array}$ \\
\hline 15.4 & Fuel Loading Models & 2001 & 2009 & Biannual & $30 \mathrm{~m}$ & RS/Landsat & Raster & Fire & Disc. & $\begin{array}{c}\text { USGS, DOI, Nature } \\
\text { Conservancy, Wildland } \\
\text { Fire Mngt. }\end{array}$ \\
\hline 15.5 & Fire Regime Groups & 2001 & 2009 & Biannual & $30 \mathrm{~m}$ & RS/Landsat & Raster & Fire & Disc. & $\begin{array}{l}\text { USGS, DOI, Nature } \\
\text { Conservancy, Wildland } \\
\text { Fire Mngt. }\end{array}$ \\
\hline 15.5 & Succession Classes & 2001 & 2009 & Biannual & $30 \mathrm{~m}$ & RS/Landsat & Raster & Vegetation & Disc. & $\begin{array}{l}\text { USGS, DOI, Nature } \\
\text { Conservancy, Wildland } \\
\text { Fire Mngt. }\end{array}$ \\
\hline 15.6 & $\begin{array}{l}\text { Vegetation Condition } \\
\text { Class }\end{array}$ & 2001 & 2009 & Biannual & $30 \mathrm{~m}$ & RS/Landsat & Raster & Vegetation & Disc. & $\begin{array}{c}\text { USGS, DOI, Nature } \\
\text { Conservancy, Wildland } \\
\text { Fire Mngt. }\end{array}$ \\
\hline 15.7 & Vegetation Departure & 2001 & 2009 & Biannual & $30 \mathrm{~m}$ & RS/Landsat & Raster & Vegetation & Disc. & $\begin{array}{l}\text { USGS, DOI, Nature } \\
\text { Conservancy, Wildland } \\
\text { Fire Mngt. }\end{array}$ \\
\hline 16 & National Land Cover D & base (NLCD) & & & & & & & & \\
\hline 16.1 & NLCD & & 2000 & 1992 & $30 \mathrm{~m}$ & RS/Landsat & Raster & LCLU & Disc. & $\begin{array}{l}\text { USGS, NOAA, EPA, } \\
\text { USDA, NRCS, USFS, } \\
\text { NPS, FWS, BLM, NASA, } \\
\text { OSM }\end{array}$ \\
\hline 16.2 & NLCD & & 2007 & 2001 & $30 \mathrm{~m}$ & RS/Landsat & Raster & LCLU & $\begin{array}{l}\text { Disc./ } \\
\text { Cont. }\end{array}$ & $\begin{array}{l}\text { USGS, NOAA, EPA, } \\
\text { USDA, NRCS, USFS, } \\
\text { NPS, FWS, BLM, NASA, } \\
\text { OSM }\end{array}$ \\
\hline 16.3 & NLCD & & 2010 & 2006 & $30 \mathrm{~m}$ & RS/Landsat & Raster & LCLU & $\begin{array}{l}\text { Disc./ } \\
\text { Cont. }\end{array}$ & $\begin{array}{l}\text { USGS, NOAA, EPA, } \\
\text { USDA, NRCS, USFS, } \\
\text { NPS, FWS, BLM, NASA, }\end{array}$ \\
\hline
\end{tabular}




\begin{tabular}{|c|c|c|c|c|c|c|c|c|c|c|}
\hline ID & Name & $\begin{array}{c}\text { Data } \\
\text { acquisition }\end{array}$ & Release & Updates & $\begin{array}{l}\text { Spatial } \\
\text { resolution }\end{array}$ & Source & Data type & Subject matter & $\begin{array}{l}\text { Variable } \\
\text { type }\end{array}$ & Developed \\
\hline & & & & & & & & & & OSM \\
\hline 16.4 & NLCD & & 2013 & 2011 & $30 \mathrm{~m}$ & RS/Landsat & Raster & LCLU & $\begin{array}{l}\text { Disc./ } \\
\text { Cont. }\end{array}$ & $\begin{array}{c}\text { USGS, NOAA, EPA, } \\
\text { USDA, NRCS, USFS, } \\
\text { NPS, FWS, BLM, NASA, } \\
\text { OSM }\end{array}$ \\
\hline 17 & $\begin{array}{l}\text { Enhanced Historical } \\
\text { Land-Use and Land- } \\
\text { Cover Data Sets of the } \\
\text { U.S. Geological } \\
\text { Survey }\end{array}$ & $\begin{array}{l}\text { Late } 1970 \mathrm{~s} \\
\text { and early } \\
1980 \mathrm{~s}\end{array}$ & & & $1: 100,000$ & $\begin{array}{l}\text { Visual } \\
\text { interp.-aerial } \\
\text { photography }\end{array}$ & $\begin{array}{l}\text { Vector } \\
\text { /Raster }\end{array}$ & LCLU & Disc. & USGS \\
\hline 18 & Land Cover Trends & $\begin{array}{c}1973,1980, \\
1986,1992, \\
\text { and } 2000\end{array}$ & 2011 & & $30 \mathrm{~m}$ & RS/Landsat & Ecoregion & LCLU Trends & Disc. & USGS \\
\hline 19 & $\begin{array}{l}\text { National Resources } \\
\text { Inventory }\end{array}$ & $1982-2010$ & 2014 & $\begin{array}{l}\text { Annually } \\
\text { (since } \\
2000)\end{array}$ & County & Field Survey & Vector & $\begin{array}{l}\text { Soil, developed } \\
\text { land, wetlands, } \\
\text { irrigation, cropland }\end{array}$ & & USDA \\
\hline 20 & $\begin{array}{l}\text { NASS Census of } \\
\text { Agriculture }\end{array}$ & $1840-2012$ & 2012 & 5 years & County & Survey & Vector & $\begin{array}{l}\text { Land use, operator } \\
\text { characteristics, } \\
\text { acreage, machinery } \\
\text { and equipment, } \\
\text { crops, livestock } \\
\text { and poultry, and } \\
\text { farming economics }\end{array}$ & $\begin{array}{l}\text { Disc./ } \\
\text { Cont. }\end{array}$ & USDA \\
\hline 21 & $\begin{array}{c}\text { NASS National } \\
\text { Cropland Data layer }\end{array}$ & 1971-2014 & Annual & & $30 \mathrm{~m}$ & RS/Landsat & Raster & Agricultural LC & Disc. & USDA NASS \\
\hline 22 & $\begin{array}{l}\text { NASS Crop Yield } \\
\text { National maps }\end{array}$ & 1971-2014 & Annual & & County & RS/Survey & Vector & $\begin{array}{l}\text { Acreage \& Yield } \\
\text { (25 crops })\end{array}$ & $\begin{array}{l}\text { Disc./ } \\
\text { Cont. }\end{array}$ & USDA NASS \\
\hline 23 & $\begin{array}{l}\text { NASS Agricultural } \\
\text { Resource Management } \\
\text { Survey (ARMS) }\end{array}$ & & Annual & & & Survey & & $\begin{array}{l}\text { Farm business and } \\
\text { household }\end{array}$ & & USDA NASS \\
\hline 24 & $\begin{array}{l}\text { Forest Inventory and } \\
\text { Analysis Program }\end{array}$ & & 1993 & & $1: 7500000$ & Field Survey & Vector & Forest variables & $\begin{array}{l}\text { Disc./ } \\
\text { Cont. }\end{array}$ & USFS \\
\hline 25 & Forest biomass & & & & $250 \mathrm{~m}$ & $\begin{array}{l}\text { FIA \& } \\
\text { Landsat }\end{array}$ & Raster & Forest biomass & Cont. & USDA/USFS \\
\hline 26 & $\begin{array}{c}\text { National Biomass and } \\
\text { Carbon Dataset for the } \\
\text { year } 2000\end{array}$ & 2000 & & & $30 \mathrm{~m}$ & RS/Landsat & Raster & Forest biomass & Cont. & WHRC \\
\hline 27 & $\begin{array}{c}\text { Biomass Resource } \\
\text { Availability }\end{array}$ & 2009 & & & County & Maps & Vector & Biomass & Cont. & DOE NREL \\
\hline 28 & $\begin{array}{l}\text { U.S. General Soil } \\
\text { Map, STATSGO2 }\end{array}$ & & & & $\begin{array}{l}1: 250000 / \\
1: 1000000\end{array}$ & $\begin{array}{c}\text { Survey/RS/L } \\
\text { andsat }\end{array}$ & Vector & Soil & Disc. & $\begin{array}{c}\text { USDA Natural Resources } \\
\text { Conservation Service }\end{array}$ \\
\hline
\end{tabular}




\begin{tabular}{|c|c|c|c|c|c|c|c|c|c|c|}
\hline ID & Name & $\begin{array}{c}\text { Data } \\
\text { acquisition }\end{array}$ & Release & Updates & $\begin{array}{l}\text { Spatial } \\
\text { resolution }\end{array}$ & Source & Data type & Subject matter & $\begin{array}{l}\text { Variable } \\
\text { type }\end{array}$ & Developed \\
\hline 29 & $\begin{array}{c}\text { Soil Survey } \\
\text { Geographic database }\end{array}$ & 2005 & 2005 & & $\begin{array}{l}1: 12000 \\
\text { to } \\
1: 63360\end{array}$ & Field survey & Vector & Soil & Disc. & $\begin{array}{c}\text { USDA Natural Resources } \\
\text { Conservation Service }\end{array}$ \\
\hline
\end{tabular}




\section{Appendix F: List of National Land Cover/Land Use Trajectories}

\begin{tabular}{|c|c|c|c|c|c|c|c|c|c|c|}
\hline ID & Name & Source & Released & Coverage & $\begin{array}{l}\text { Time } \\
\text { life }\end{array}$ & $\begin{array}{l}\text { Modeling } \\
\text { approach }\end{array}$ & $\begin{array}{l}\text { Driving } \\
\text { variables }\end{array}$ & $\begin{array}{l}\text { Spatial } \\
\text { resolution }\end{array}$ & $\begin{array}{l}\text { Temporal } \\
\text { resolution }\end{array}$ & Methods \\
\hline 1 & $\begin{array}{l}\text { Millennium } \\
\text { Ecosystem } \\
\text { Assessment }\end{array}$ & $\begin{array}{l}\text { Millennium } \\
\text { Ecosystem } \\
\text { Assessment }\end{array}$ & 2005 & $\begin{array}{l}\text { World } \\
\text { regions }\end{array}$ & 2100 & $\begin{array}{l}\text { Global } \\
\text { orchestration, } \\
\text { Order from } \\
\text { strength, } \\
\text { Adapting } \\
\text { mosaic, } \\
\text { Technogarden }\end{array}$ & $\begin{array}{l}\text { Ecosystem } \\
\text { services }\end{array}$ & $\begin{array}{l}\text { World } \\
\text { regions }\end{array}$ & $\begin{array}{l}2000 \\
2050 \\
2100\end{array}$ & $\begin{array}{c}\text { IMPACT; } \\
\text { WaterGAP;AI } \\
\text { M; IMAGE } \\
\text { 2.2; Ecopath- } \\
\text { Ecosim }\end{array}$ \\
\hline 2 & $\begin{array}{l}\text { Global Land Use } \\
\text { Model (GLM) }\end{array}$ & $\begin{array}{l}\text { University of } \\
\text { Maryland }\end{array}$ & 2006 & Global & $\begin{array}{l}1700- \\
2000\end{array}$ & & $\begin{array}{l}\text { Fractional land- } \\
\text { use; land use } \\
\text { transitions }\end{array}$ & 1 degree & Annual & GLM \\
\hline 3 & $\begin{array}{l}\text { Global Land Use } \\
\text { Model (GLM) }\end{array}$ & $\begin{array}{l}\text { University of } \\
\text { Maryland }\end{array}$ & 2011 & Global & $\begin{array}{l}1500- \\
2100\end{array}$ & $\begin{array}{l}\text { RCP8.5; RCP6- } \\
\text { AIM; RCP4.5- } \\
\text { GCAM; } \\
\text { RCP2.6- } \\
\text { IMAGE }\end{array}$ & $\begin{array}{l}\text { Land use } \\
\text { transitions; } \\
\text { secondary land } \\
\text { area \& age }\end{array}$ & $0.5 \mathrm{deg}$. & Annual & GLM \\
\hline 4 & $\begin{array}{l}\text { Integrated Climate and } \\
\text { Land Use Scenarios }\end{array}$ & EPA-ICLUS & 2010 & CONUS & 2100 & $\begin{array}{l}\mathrm{A} 1, \mathrm{~A} 2, \mathrm{~B} 1, \mathrm{~B} 2 \\
\text { SRES }\end{array}$ & $\begin{array}{l}\text { Residential } \\
\text { housing }\end{array}$ & $100 \mathrm{~m}$ & Decadal & $\begin{array}{l}\text { Gravity } \\
\text { model }\end{array}$ \\
\hline 5 & $\begin{array}{l}\text { Integrated Climate and } \\
\text { Land Use Scenarios }\end{array}$ & EPA-ICLUS & 2010 & CONUS & 2100 & $\begin{array}{l}\text { A1, A2, B1, B2 } \\
\text { SRES }\end{array}$ & $\begin{array}{l}\text { Impervious } \\
\text { surfaces }\end{array}$ & $100 \mathrm{~m}$ & Decadal & $\begin{array}{l}\text { Gravity } \\
\text { model }\end{array}$ \\
\hline 6 & $\begin{array}{l}\text { Economic-based } \\
\text { projections of future } \\
\text { land-use }\end{array}$ & $\begin{array}{l}\text { University of } \\
\text { Wisconsin- } \\
\text { Madison }\end{array}$ & 2012 & CONUS & 2051 & $\begin{array}{l}\text { A1, A2, B1, B2 } \\
\text { SRES }\end{array}$ & LCLU & County & $2001-2051$ & $\begin{array}{c}\text { Econometric } \\
\text { land use } \\
\text { model }\end{array}$ \\
\hline 7 & Housing density & $\begin{array}{l}\text { University of } \\
\text { Wisconsin- } \\
\text { Madison }\end{array}$ & 2014 & CONUS & 2030 & $\begin{array}{l}\text { A1, A2, B1, B2 } \\
\text { SRES }\end{array}$ & $\begin{array}{c}\text { Housing } \\
\text { growth/ } \\
\text { Protected areas }\end{array}$ & $\begin{array}{l}\text { Protected } \\
\text { areas }\end{array}$ & Decadal & \\
\hline 8 & $\begin{array}{l}\text { Land-Use and Land- } \\
\text { Cover Scenarios and } \\
\text { Spatial Modeling }\end{array}$ & USGS & 2012 & $\begin{array}{l}\text { CONUS- } \\
\text { Level } 3 \\
\text { Ecoregions }\end{array}$ & 2100 & $\begin{array}{l}\text { A1B, A2, B1, } \\
\text { B2 SRES }\end{array}$ & LCLU & $250 \mathrm{~m}$ & Decadal & FORE-SCE \\
\hline & $\begin{array}{l}\text { The Marine West } \\
\text { Coast Forests } \\
\text { Ecoregion }\end{array}$ & USGS & 2012 & $\begin{array}{l}\text { CONUS- } \\
\text { Level } 3 \\
\text { Ecoregions }\end{array}$ & 2100 & $\begin{array}{l}\text { A1B, A2, B1, } \\
\text { B2 SRES }\end{array}$ & Forest & $250 \mathrm{~m}$ & Decadal & FORE-SCE \\
\hline 10 & $\begin{array}{c}\text { USFS RPA } \\
\text { Assessment } 2010\end{array}$ & USFS & 2010 & $\begin{array}{l}\text { CONUS/ } \\
\text { Regional }\end{array}$ & $\begin{array}{c}2010- \\
2060(50 \\
\text { years })\end{array}$ & $\begin{array}{l}\text { A1B, A2, B2 } \\
\text { SRES }\end{array}$ & $\begin{array}{l}\text { Ecosystem } \\
\text { services }\end{array}$ & & Decadal & $\begin{array}{c}\text { Population/ } \\
\text { Econometric } \\
\text { model }\end{array}$ \\
\hline
\end{tabular}

